\title{
A Historical Perspective on Administrative JuRisDiction in LATIN AMERICA: CONTINENTAL European Tradition Versus U.S. INFLUENCE
}

\author{
Ricardo Perlingeiro* \\ Fluminense Federal University, Brazil
}

\begin{abstract}
From the perspective of U.S. influence, this text analyses the history of administrative jurisdiction, starting from the 19th Century, in the 19 Latin American countries of Iberian origin (Argentina, Bolivia, Brazil, Chile, Colombia, Costa Rica, Cuba, Ecuador, El Salvador, Guatemala, Honduras, Mexico, Nicaragua, Panama, Paraguay, Peru, Dominican Republic, Uruguay and Venezuela). The analysis includes the U.S. unified judicial system (generalized courts) and procedural due process of law to decisions by the administrative authorities, the fertile field of primary jurisdiction, which is in conflict with the Continental European tradition firmly established in Latin American administrative law. While setting out the contradictions of administrative jurisdiction in Latin American countries that result from importing rules without putting them in the proper context, the text seeks to identify trends and create perspective to build a model of administrative justice specific to Latin America, drawing on the accumulated experience of the United States and Continental Europe.
\end{abstract}

\section{CONTENTS}

I. INTRODUCTION 244

II. Administrative Jurisdiction: Judicial, Non-Judicial and Hybrid Model 248

A. Constitution of Cadiz of 1812. Junta Grande of 1811 (Argentina). Belgian Constitution of 1831. Reglamento para el Arreglo de la Autoridad Ejecutiva Provisoria de Chile (1811). Loi des 16 et 24 août 1790. Ley de Santamaría Paredes. Administrative Court of the Land of Baden of 1863

1 English version of the chapter included in the collective work published in Germany: KARLPeter Sommermann \& Bert Schaffarzik, Handbuch der Geschichte der VerwaltungsgerichtSbarkeit in Deutschland und Europa [Manual of History of Administrative JurisdicTION IN GeRMANY AND EUROPE] 1500 (2017) available at http://amzn.to/1DQNIBX.

* Full Professor of the Faculty of Law of Fluminense Federal University (Niterói, Rio de Janeiro). Federal Appellate Judge (Desembargador Federal) of the Federal Regional Court of the $2^{\text {nd }}$ Region (Rio de Janeiro). Guest Visiting researcher of Deutsches Forschungsinstitut für öffentliche Verwaltung Speyer - FÖV (2006-2007).

(cc) BY-NC-ND $(C 2015$ Ricardo Perlingeiro, licensee De Gruyter Open. 
B. Lack of Independence of French Administrative Litigation (Contentieux Administratif) and the Unified Judicial System in Latin America in the $19^{\text {th }}$ Century: La Justice Déléguée of 1872 253

C. The Unified Judicial System in Latin America in the $19^{\text {th }}$ Century and Questions of Governance.

D. The Specialization of Jurisdiction in Europe and the Emergence of Administrative Law.

E. The Evolution of the Unified Judicial System in the United States: Interstate Commerce Commission (ICC) of 1887... 257

F. Models of Administrative Jurisdiction in Latin America in the $19^{\text {th }}$ and $20^{\text {th }}$ Centuries

1. Hybrid (Judicial and Non Judicial) Administrative Jurisdiction: Honduras, Brazil.....

2. Non-Judicial Administrative Jurisdiction: Bolivia, Panama, Dominican Republic, Colombia, Guatemala, Ecuador, Uruguay, Mexico.

3. Dualist Judicial Jurisdiction: Colombia, Nicaragua, Panama, Ecuador, Guatemala, Dominican Republic

4. Monist Judicial Jurisdiction (uninterrupted period): Chile, Argentina, Venezuela, Paraguay, México, Costa Rica, Peru, El Salvador, Cuba, Brazil

5. Monist Judicial Jurisdiction (Limited Period): Colombia, Guatemala, Dominican Republic

6. Monist Judicial Jurisdiction (Intermittent Periods): Nicaragua, Honduras, Ecuador, Panama, Bolivia

7. Monist Judicial Jurisdiction (Currently in Effect and with Specialised Bodies): Chile, Argentina, Venezuela, Paraguay, Mexico, Costa Rica, Peru, El Salvador, Cuba, Bolivia, Brazil, Panama, Nicaragua, Honduras and Ecuador 267

H. Developmental and Comparative Framework of the Autonomous Administrative Jurisdiction Under the Latin American Constitutions 268

1. JUDICIAL JURISDICTION 269

2. NON-JUDICIAL JURISDICTION 269 


\section{HYBRID JURISDICTION (NON-JUDICIAL AND} JUDICIAL)

III. Administrative Decisions Preceded by Due Process OF LAW

A. Signs of U.S. Due Process of Law in Latin America: The $5^{\text {th }}(1791)$ and $14^{\text {th }}(1868)$ Amendments of the U.S.Constitution 270

B. Origin of Due Process of Law: Magna Carta of 1215, Liberty of Subject Act (28 Edward 3) of 1354, Observance of Due Process of Law Act (42 Edward 3) of 1368

C. Right to a Fair Trial on the International Scene: Declaration of the Rights of Man and of the Citizen of 1789 (Déclaration des Droits de l'Homme et du Citoyen), Universal Declaration of Human Rights of 1948, European Human Rights Convention of 1950, International Covenant on Political and Civil Rights of 1966, African Charter on Human and Peoples' Rights of 1981, Charter of Fundamental Rights of the European Union of 2000, American Convention on Human Rights of 1969

D. Administrative Due Process of Law in Latin-American Constitutions and Laws

E. Case Law of the European and Inter-American Courts of Human Rights: Independence and Impartiality in Non-Judicial Administrative Proceedings, and Due Process of Law Prior to Administrative Decisions

F. Distinction Between the Judicial Administrative Proceeding (Processo Administrativo Judicial), Non-Judicial Administrative Proceeding (Processo Administrativo não Judicial) and Administrative Procedure (Procedimento Administrativo) 278

G. Administrative Due Process Prior to Decisions by Administrative Authorities in Latin America 281

IV. Closing Considerations 285 


\section{INTRODUCTION}

The boom in public-law conflicts in Brazilian courts ${ }^{3}$ has been associated with an identity crisis in its model of administrative justice ${ }^{4}$, which bears traces of the U.S. legal system even though it is discordant with the Brazilian culture of administrative law, which is still tied to the French and German models in many respects. ${ }^{5}$ On that subject, Rivero warned that "even in those aspects in which Anglo-Saxon influence reaches its high point in Latin-American administrative law, it does not appear to extend to legal technique: the sources, categories and methods of reasoning remain the same as those of Continental European law, with few exceptions". ${ }^{6}$

3 "The total number of cases increased from 83.4 million in 2009 to 92.2 million in the year 2012; out of that total, 28.2 million (31\%) were new cases and 64 million (69\%) had been pending from prior years. Moreover, in 2012, each judge tried an average of 1,450 cases, an increase of $1.4 \%$ relative to 2011 . Although the judges are trying more cases each year, the total number of judgments ( 1 million or $4.7 \%$ ) was lower than the increase in new cases ( 2.2 million or $8.4 \%$ ), which means that the number of cases tried was $12 \%$ lower than the total number of cases entered in the records. There is no way to determine the exact percentage of cases that involved the public administrative authorities, but such disputes are estimated to account for the majority of them, over $50 \%$ of the total number. There are four indications that lead to this conclusion: (i) in 2012, out of the total number of 64 million cases pending from prior years, $39.9 \%$ were tax enforcement cases, while, in $2013,41.4 \%$ of the total of 66.7 million pending cases were tax enforcement cases; (ii) over the past 20 years, the public authorities have been a party to $90 \%$ of the total number of judicial proceedings tried in the Federal Supreme Court (Supremo Tribunal Federal or "STF"), also known as the Constitutional Court; (iii) 498 out of the 693 Supreme Court cases with general repercussions, i.e., $71 \%$ of them, concerned public law (administrative law, tax law and social security law); (iv) dos 721 recursos de efeito repetitivo no Superior Tribunal de Justiça / STJ [Superior Court Of Justice], 360 of the 721 precedentsetting Supreme Courts appeals concerned public law, which therefore amounts to $50 \%$ of the total." (Conselho Nacional De Justiça, Justiça em números [Justice in Numbers]: 2014 [Reference Year 2013] 32 et seq. (2014), in Ricardo Perlingeiro, O Devido Processo Administrativo e a Tutela Judicial Efetiva: Um NovoOlhar? [Administrative Due Process of Law and Effective Judicial Protection: A New Perspective?], 239 ReVISTA DE Processo, 293 (2015)).

4 It is necessary to point out the scope and context of the terminology used in this text. The expression "contencioso administrativo" [administrative litigation] refers to claims or challenges by an individual against the actions of an administrative authority. The expression "administrative jurisdiction" means the jurisdictional service intended to resolve administrative litigation, and "administrative justice" refers to the state bodies responsible for such jurisdictional action (Universidade Federal Fluminense, AcAdemic Project of the Postgraduate Program in Administrative Justice - PPGJA/UfF (2008) available at http://bit.ly/1A1xFy4).

5 See Perlingeiro, supra note 3.

6 Jean Rivero, Curso de direito administrativo [Administrative law course] 221 (J. Cretella Jr. trans., 2004) (Braz.). 
In early $19^{\text {th }}$-Century Europe, many considered administrative jurisdiction to be an attribute of the Executive Branch itself, inherent in its power of "autotutela" [power to correct its own decisions and errors]. Later, however, such jurisdiction became divided between the public administrative authorities and autonomous courts, so that a judicial appeal to the courts became the second level of authority of an administrative jurisdiction that originated in the public authorities. Since the late $19^{\text {th }}$ Century, however, Continental Europe has shown a preference for entrusting administrative dispute resolution exclusively to courts that tend to be specialised and have broad powers of review, in order to make up for a system of administrative law in which the authorities lack effective autonomous decision-making power. ${ }^{7}$

In the United States, on the other hand, with the development of its unified traditional judicial system (generalized courts), the tendency is to divide the exercise of the administrative jurisdictional activities between the Executive and the Judiciary, not as in the beginnings of European administrative justice ${ }^{8}$ but rather based on a model in which administrative decisions are made by authorities who have a certain degree of independence (quasi-judicial bodies, administrative tribunals), in a non-judicial proceeding with guarantees approximating due process of law; the - nonspecialised - Judiciary can modify such decisions only if they are obviously unreasonable and the authority of the courts to examine the underlying facts of the case is restricted (limited judicial review). ${ }^{9}$

This culture of common law in Latin America, without prior contextualization, creates a risk of driving the model of administrative justice to either of two extremes: on the one hand, duplicate jurisdictions, with public authorities and courts which have similar independence, specialisation and broad powers of review, resulting in higher costs, uncertainty and delays in conflict resolution; on the other, an absence of jurisdiction, since administrative authorities that lack independence and are therefore incapable of ensuring a fair non-judicial administrative proceeding co-exist with non-

7 See Giulio Napolitano, Igrandi Sistemi del Dritto Amminstravo [The Main Systems of Administrative Law], in Diritto amministrativo comparato [Comparative AdministraTIVE LAW] 45 (2007) (It.).

8 García de Enterría takes the opposite position that the current judicial review is a regression to the "arcaico contencioso europeu do século XIX" [archaic European litigation of the $19^{\text {th }}$ Century] (Eduardo García de Enterría, Democracia, Jueces y Control de la Administración [Democracy, Judges and Control of the Administration] 172 (Civitas 1995) (Spain).

9 On the difference between the Ibero-American "judicialist system" and the U.S. model, see Juan Carlos Cassagne, El principio de legalidade y el control judicial de la discricionalidad administrativa [The Rule of LaW and Judicial Review of Administrative Discretion] 71 (2009) (Arg.); see generally Michael Asimow, Five Models of Administrative Adjudication, 63 Aм. J. Coмp. L. 3, 3-32 (2015), available at http://bit. ly/1yp8y4i; on independence and impartiality in administrative tribunals in English law, see Peter Cane, Administrative Law 96 (5 $5^{\text {th }}$ ed. 2011). 
specialised courts that choose to defer to the technical expertise and regulatory power of the authorities or else, with the same practical effect of such "administrative deference", opt to decide the case themselves even without the proper expertise to try to subject matter sub judice.

In either case, the administrative authorities and courts may weaken themselves as jurisdictional bodies, especially from the standpoint of their reliability vis-à-vis one another and in the eyes of the private claimants.

The Brazilian model tends towards the absence of jurisdiction: with the advent of the Republic, in 1891, under the avowed influence of U.S. constitutionalism an undivided judicial system was set up for both the administrative jurisdiction and ordinary jurisdiction (generalized courts), which still remains in effect today; moreover, the 1988 Constitution raised (non-judicial) administrative due process of law to the category of a fundamental right, making it a prerequisite for administrative decisions restricting individual rights.

Since the public administrative authorities lack prerogatives to settle conflicts with effective independence, however, the Judiciary is being asked to perform increasingly intense judicial review in its supervision of administrative actions. This results in widespread frustration: on the one hand, with courts that defer to the authorities (as is typical of the U.S. model with its quasi-judicial bodies), on the other, vis-à-vis courts often criticised by the authorities for going too far with the intensity of supervision (typical of the Continental-European model with its dualist and specialised jurisdiction).

One puzzling example in Brazil is the need for judicial intervention in order to enforce decisions by the tax authorities. There are approximately 25 million tax enforcement claims in progress, representing $40 \%$ of the judicial proceedings in progress in the nation. ${ }^{10}$ In fact, the Brazilian legal community has the general impression that the public administrative authorities are not empowered to initiate acts of enforcement for their decisions for their own account or even to conduct fair proceedings that result in restrictive decisions, especially in the states and municipalities of inland Brazil where, besides lacking independence, the tax officials do not always have legal expertise.

Paradoxically, however, it is feared that "dejudicialising" tax enforcement claims would increase the number of judicial conflicts, so great is the possibility of administrative errors; it is therefore thought better for the enforcement action to be carried out ab initio in the Judiciary, with any judicial resulting errors corrected in court, as well. ${ }^{11}$ As shown above, the ad-

10 In 2012, 25 million tax enforcement cases were pending in Brazilian courts, which amounts to $39.9 \%$ of all litigation in process (See Conselho Nacional De Justiça, JustiçA EM NúMERos [Justice In NumBers] 293-303 (2013) (Braz.).).

11 Marcos de Vasconcellos, Judges of the STJ [Superior Court of Justice] Are Against Tax Enforcement Without a Judge, Revista Consultor Jurídico, June 8, 2012; see also Fernanda Duarte, A Execução E Uma Questão de Justiça? [Is Enforcement a Question of Justice?], 13 Revista da Section Judiciária do Rio de Janeiro 45 (2005). See also Maria F. Erdelyi, Proposta de Execução Fiscal da Fazenda E Alvo de Criticas [Proposal of 
ministrative authorities are practically deprived of any role in tax law, since the power to enforce administrative decisions is relegated to the Judiciary as though it were the longa manus of the administrative authorities; thus, even though enforcement is a typical administrative function (attribute of self-enforceability of administrative decisions), the power to resolve tax enforcement conflicts is concentrated in the hands of a non-specialised judge.

In Germany, tax decisions are enforced by the tax authorities themselves. ${ }^{12}$ The high degree of credibility of the German public administrative authorities, inherited from Prussian professionalism, ${ }^{13}$ gives people a feeling of impartiality even without prerogatives guaranteeing effective independence, so that, in practice, the specialised judges, despite their broad powers, are not often called upon to exercise them. The reality of the German model of administrative justice demonstrates that the Continental-European system is not synonymous with excessive judicial review, which, on the contrary, is a symptom of debilitated public administrative authorities; such weakness might be aggravated if other countries adopted models of administrative justice without making the necessary adjustments to their own specific cultural reality.

This article will try to show that episodic influence of U.S. constitutionalism in Latin American countries in the wake of their republican independence movements in the $19^{\text {th }}$ Century led the majority of the new nations (e.g., Brazil) to a system of unified jurisdiction in the Judiciary (monist system), breaking off from its origins in Continental Europe, which adhered to a dualist judicial model in which the administrative jurisdiction is structured separately from the jurisdiction over private law.

Moreover, in the same way that Brazil can be criticised for ignoring the new version of the French Conseil d'état in the late $19^{\text {th }}$ Century (justice déléguée), it is possible that, in the future, no one will be able to understand why Latin-American countries maintained the system of unified jurisdiction without taking into consideration the corresponding evolution of U.S. administrative law.

Against that backdrop, the purpose of this study is explore topics inherent in the basic structure of a model of administrative justice ${ }^{14}$ as a basis for analysing the evolution from the $19^{\text {th }}$ to $21^{\text {st }}$ Centuries of administrative justice systems in the Latin American States, ${ }^{15}$ comparing their experiences,

Tax Enforcement by the Public Tax Authority is Subject to Criticism], Revista ConsulTOR JURÍDICO, Nov. 27, 2007.

12 Abgabenordnung [AO] [Tax Code], $\S \S 249$ et seq.

13 Jacques Ziller, Administrations comparées: les systèmes Politico-ADMinistratifs de l'Europe des Douze [Compared Administrations: the Politico-administrative Systems of the Europe of the Twelve] 381 (1993) (Fr.).

14 Criteria partly inspired by the system developed by Michael Asimow. See Asimow, supra note 9.

15 There are 19 Latin-American countries of Iberian origin: Argentina, Bolivia, Brazil, Chile, Colombia, Costa Rica, Cuba, Ecuador, El Salvador, Guatemala, Honduras, Mexico, Nicaragua, Panama, Paraguay, Peru, Dominican Republic, Uruguay and Venezuela. 
recent changes, oscillations and established tendencies in a search for a new direction: should we reconcile ourselves to the Continental-European model, approximate the evolution in the US model, or else start building the identity of a specific model of our own? ${ }^{16}$

\title{
II. Administrative Jurisdiction: Judicial, Non-Judicial and Hybrid Model
}

\author{
A. Constitution of Cadiz of 1812. Junta Grande of 1811 \\ (Argentina). Belgian Constitution of 1831. Reglamento Para \\ el Arreglo de la Autoridad Ejecutiva Provisoria de Chile \\ (1811). Loi des 16 et 24 août 1790. Ley de Santamaría Paredes. \\ Administrative Court of the Land of Baden of 1863
}

According to Cassagne, there has been a misinterpretation of the scope of the constitutional sources and their historical bases: he argues that the system of unified jurisdiction in Latin America is mistakenly associated with the U.S. model, whereas in fact the judicialismo puro [supervision of administrative decisions exclusively by the Judiciary] of the Latin-American systems of administrative justice originated in the Constitution of Cadiz of 1812, Article 243 of which imposes an absolute limit on the exercise of jurisdictional functions by bodies or tribunals pertaining to the structure of the Executive Branch. ${ }^{17}$

Nevertheless, it is quite likely that the liberal ideas of La Pepa originated in the North-American colonies and England, from which the monist judicial system would also be imported later. According to Congleton, the list of functions of the Legislative Branch contained in Article 131 of Cadiz did not correspond to anything in Continental Europe of 1812 but rather to the U.S. Legislature and thus, implicitly, to the English Parliament. ${ }^{18}$ The truth is that certain Spanish-American Constitutions had already been approved before 1812, as in the case of Argentina, Chile and Venezuela in $1811 .{ }^{19}$

The Reglamento Orgánico of 22 October 1811 of the Junta Grande, considered the first proto-Argentine Constitution, "organically [adopted]

16 According to Rivero, in the current state of the art, it would be rash to conclude that a real Latin-American system administrative law exists (RIVERo, supra note 6, at 222).

17 See Cassagne, supra note 9, at 67, 71.

18 Roger D. Congleton, Early Spanish Liberalism and Const.al Political Economy: The CÁdiz Const. of 1812 18-19 (2010).

19 See generally Albert P. Blaustein, The U.S. Constitution: America's Most Important Export, 4 Issues of Democracy 6, (2004). 
the tripartite form of government". ${ }^{20}$ Article 7 of Section 2 on the Executive Branch reads as follows:

The Executive Branch shall not hear any judicial cases or attend to any lawsuits, whether pending or closed, nor order any trials to be re-opened, nor change the system of administration of justice, nor hear the cases of higher or lower magistrates or other subordinate judges and civil servants, which cases shall be reserved for the Tribunal de la Real Audiencia or Comisión, which, where appropriate, shall appoint the Junta Conservadora.

It is worth pointing out the origin in the U.S. of the Junta Grande of $22 \mathrm{Oc}$ tober 1811, as noted by Valadés:

[...] The Secretary of the Government Junta, Mariano Moreno, did a translation of the US Constitution of 1787 , to which he made some changes in the numbering and contents. Certain authors consider that study to be a sort of rough draft of the constitution [...] On 18 December 1810, the First Junta interpreted the Reglamento of 25 May and decided that it should also include parliamentary representatives from the inland areas of the Vice-Regency. When the number of its members reached twenty-two in 1811, it changed its name to Conservative Junta (i.and., conserving the rights of Fernando VII), more commonly known as the Second Junta or Junta Grande. [...]. ${ }^{21}$

If that thesis is correct, Moreno's work may be considered the first organic constitutional initiative of the Republic of Argentina. ${ }^{22}$

In fact, the above-cited Article 243 of the Constitution of Cadiz (according to which neither the Cortes nor the King could exercise under any circumstances judicial functions, rule itself competent to hear pending cases or even order "juicios fenecidos" to be reopened) and Article 242 (according which the courts alone have the power to apply the laws in civil and criminal cases) still have correlations with the provisions of the $19^{\text {th }}$ Centu-

20 José Rafael López Rosas, Historia constitucional argentina [Const.al History Argentina] 143 ( $2^{\text {nd }}$ ed. 1970); Francisco Miguel Ávila Ricci, Nueva Constitución nacional: Desde la historiografía institucional argentina [New Const.: From Argentina Historiography] 122 (1997); Luis R. Longhi, Génesis e Historia del Derecho Constitucional Argentino y Comparado. Buenos Aires: Bibliográfica Argentina, 1945. t. I. nota 4, p. 258 in Constituiciones iberoamericanas: [IBero-American Const.s] 6 n.10 (Néstor Pedro Sagüés ed., 2006).

${ }^{21}$ Diego Valadés, Introducción Histórica: Proceso Constitucional Argentino [Historical Introduction: Argentine Constitutional Process], in Néstor Pedro Sagüés, ConstituICiones iberoamericanas [Ibero-American Consts.]: Argentina 4 (2006).

22 Id. at 5. 
ry Latin-American Constitutions of Chile, ${ }^{23}$ Ecuador, ${ }^{24}$ Argentina, ${ }^{25}$ Peru ${ }^{26}$ and Bolivia. ${ }^{27}$

However, the use of the expression "civil and criminal courts" in Article 242 makes it clear that the focus of the provisions is not on preventing administrative dispute resolution by the Executive Branch; rather, the Executive was not supposed to interfere with functions of the Judiciary which, at the time, outside of criminal law, were mainly associated with jurisdiction over private-law cases (even if the public administrative authorities were involved in them), rather than constituting an administrative jurisdiction per se.

Rivero interprets the expression civil rights in Article 92 of the Belgian Constitution of 1831 as follows (in reference to the monist judicial system) ${ }^{28}$ : "by 'civil rights', we are to understand all citizens' rights, even those against the State, with the sole exception of interests". ${ }^{29}$ In other words, civil rights were the counterpart of political rights, which are identified with legitimate interests (intérêts légitimes), which may also be supervised by the judge according to Article 93 of the Belgian Constitution of 1831.

In that respect, the notion of "civil rights and obligations", as expressed in Article 6 of the European Convention on Human Rights, has always been controversial in the European Court of Human Rights. A draft protocol has been proposed, rewording Article 6 to extend its scope to include any public law issues, but no consensus was reached. This restriction, however, it must be said, is not found in the American Convention on $\mathrm{Hu}$ man Rights, Article 8 of which provides that the guarantees of due process of law are applicable to "rights and obligations of a civil, labor, fiscal, or any other nature". ${ }^{30}$

A good deal light is shed on this subject by Article 9 of the Reglamento para el Arreglo de la Autoridad Ejecutiva Provisoria de Chile, of 14 August

23 Constitución Política de la República de Chile [C.P.] (1828) art. 85.3; Constitución Política de la República de Chile [C.P.] (1833) art. 108.

24 Const. of ECuAdor (1869) art. 73.

25 Const. of Argentina (1811) art. 7; Const. of Argentina (1813) art. 153; ch. II, art. 1, Const. of Argentina (1815) (Arg.); Const. of Argentina; Const. of Argentina (1816)§ 3, ch. 2, art. 3; Const. of Argentina (1817)§ 3, ch. 2, art. 4,; Const. of Argentina (1856); art. 92,; Const. of Argentina (1860) art. 95.

26 Const. of Peru (1823) art. 81.3; Const. of Peru (1823) art. 127; Const. of Peru (1828) art. 91; Const. of Peru (1834) art. 86.4; Const. of Peru (1834) art. 136.3; Const. of Peru (1839) art. 88.6; Const. of Peru (1839) art. 141.2; Const. of Peru (1860) art. 43.

27 Const. of Bolivia (1826) art. 115; Const. of Bolivia (1831) art. 118; Const. of BoLIVIA(1834) art. 120.

28 Const. of Belgium (1831) art. 92, (Belg.); art. 93.

29 Rivero, supra note 6, at 169.

30 See Ireneu Cabral Barreto, A Convenção Europeia dos Direitos do Homem anotada [Annotated European Convention of Human Rights] 150 (4 $4^{\text {th }}$ ed. 2010). 
1811, considered the first Chilean Constitution: ${ }^{31}$ "The executive authority shall hear no judicial cases between the parties, unless solely concerning matters of the government [acte du gouvernement], public treasury and war"; in other words, only governmental issues were admitted for hearing by the Executive, issues that were inherent in the executive powers and over which it had exclusive jurisdiction to decide. Worded differently, but with the same practical effect, the Constitution of Paraguay of $1870^{32}$ in the late $19^{\text {th }}$ Century prohibited the Executive from ruling on administrative disputes (contentieux administratifs - a rather fluid and restrictive expression at the time). In fact, the Executive was prohibited from ruling on conflicts that did not originate in administrative actions or interests, that is to say, the Judiciary had the sole authority to settle "administrative disputes", which tended to be understood as private-law conflicts involving administrative authorities.

What was considered to be a governmental issue and administrative issue is close to what would now be an administrative action and legitimate interest. Accordingly to the scholarly writings at the time, from the point of view of administrative jurisdiction, the following parallel can be drawn: interest versus right; poder gracioso versus poder contencioso; governmental issues versus judicial issues; matters subjects to judicial review versus matters that are not. ${ }^{33}$ Otto Mayer, however, in his late $19^{\text {th }}$ Century work never accepted the category of governmental actions [actes $d u$ government]; according to him, state actions may be legislative, judicial or administrative, never governmental, which would merely serve to justify an immunity. ${ }^{34}$

From that point of view, the Spanish Constitution of 1812 was not contrary to the French Law of 16 and 24 August 1790 (Loi des 16 et 24 aôut 1790), according to which judicial functions are forever separate and distinct from administrative functions so that judges cannot, under penalty of judicial misconduct, interfere with the operations of administrative bodies or summon administrative authorities to appear before them by rea-

31 Reglamento para el Arreglo de la Autoridad Ejecutiva Provisoria de Chile [Regulations Under The Temporary Executive Authority Of Chile], Agosto 14, 1811, (Chile).

32 Const. of Paraguay (1870) art. 114.

33 Teodosio Lares, Lecciones de derecho administrative [Lessons in Administrative LAW] 16, 60, 365 (1852).

34 Otto Mayer, Derecho administrativo alemán [German Administrative Law] 3-5 (1982)(Arg.). Translated from the French version by Horacio H. Heredia et al. (Отто Mayer, Le Droit Administratif Allemand 1904). On the subject of the disputes about the conflict between the governmental powers and activities of administrative litigation at the time, see Jaun R. Fernández Torres, La Pugna Entre la Administración y los Tribunales Ordinarios Como Rasgo Sobresaliente del Primer Constitucionalismo Español [The Struggle Between the Administration and the Courts as Regular Feature Highlights of First Spanish Constitutionalism], in HISTORIA LEGAL DE LA JURISDICCIÓN COntencioso-Administrativa [Legal History of Administrative Disputes]: 1845-1998 31-79 (2007). 
son of their functions. Nor is the Spanish Constitution incompatible with Chapter V, Article 3 of the French Constitution of 1791, according to which the courts must not interfere with administrative functions or summon administrative authorities before them by reason of their functions.

It is true that the Constitution of Cadiz prohibited the performance of judicial functions by the Executive but its most relevant contribution was that it helped create an administrative jurisdiction in Spain in 1888 (Ley de Santamaría Paredes), since at the time it was out of the question to submit certain issues of administrative law to the Judiciary; in other words, it was not considered appropriate for judges to rule on governmental questions or other issues exclusively pertaining to the public administrative authorities. ${ }^{35}$ This remained an outgrowth of the influence of the great importance of the independence of the administrative jurisdiction established in French law on the basis of the "justice délleguée" of the Conseil d'état. ${ }^{36}$

In this context, the new jurisdictional functions of the Spanish State, now specialised, and the administrative jurisdiction in the judicial sphere, in general, like that of the Land of Baden a few years previously, in $1863,{ }^{37}$ had a point in common with the Belgian Constitution of $1831,{ }^{38}$ which was capable of translating the unified judicial model of common law into a "continentalised" version, reconciling the Judiciary with an administrative jurisdiction. Until then, such an administration jurisdiction belonged exclusively to the French system of justice retenue. All of these new functions tended to create a jurisdiction that was autonomous vis-à-vis the public administrative authorities.

In the opinion of Rivero, who recognises the origin of the system of unified jurisdiction over civil and administrative cases in Anglo-Saxon law, the source of inspiration of the Latin-American countries that have consecrated and maintained judicial unity was the Belgian Constitution of 1831 . It is true that the laws and Constitution of Belgium did not escape the attention of the Latin-American authors of the period; $;^{39}$ but it was really the English and U.S. systems that they often cited, considering them to be more appropriate to liberalism, as a counterpoint to the French model of administrative justice that allowed the public administrative authorities to judge themselves. ${ }^{40}$

35 Leticia Fontestad Portalés, La Jurisdicción Contencioso-Administrativa en España [Administrative Jurisdiction in Spain], 10 RevisTA CEJ 62, 62-72 (2006) (Braz.).

36 Loi du 24 mai 1872 portant réorganisation du Conseil d'Etat [Law of 24 May 1872 on the Reorganisation of the State Council] (Fr.); see David Capitant, The Public Ministry vis-à-vis the Administrative Jurisdictions in France, 34 REvISTA CEJ 56, 56-61 (2006).

37 Gesetz Betreffend die Organisation der Inneren Verwaltung [Law on the Organisation of Internal Administration], Oct. 5, 1863 (Ger.).

38 Const. of Belgium (1831). art. 92; art. 93.,

39 The Belgian law of the time is featured in the following work: Augusto Olympio VIveiros De Castro, Tratado de sciencia da Administração e direito administrativo [TREATISE ON THE SCIENCE OF ADMINISTRATION AND ADMINISTRATIVE LAW] 655-88 (1914).

40 On the subject of the influence of the liberals on the incorporation of the unified judicial system, see Rivero, supra note 6, at 153. 


\section{B. LACK OF INDEPENDENCE OF FrENCH AdMinistrative Litigation (Contentieux Administratif) and the Unified Judicial System IN Latin America in the 19 ${ }^{\text {Th }}$ Century: La Justice Déléguée of 1872}

In fact, in the first half of the $19^{\text {th }}$ Century, in the countries of Hispanic origin and in Brazil, with the advent of its Republic in 1889, the debate that arose in Latin America concerned the lack of independence of French administrative litigation (contentieux administratif). ${ }^{41}$ Since, at the time, the Judiciary was conceived of as the only autonomous state structure, it alone was considered responsible for settling administrative disputes; the desire for independence in the administrative jurisdiction was therefore the decisive factor for the spread of the system of unified jurisdiction over civil and administrative cases through Latin America.

Margáin Manautou, for examples, recalls that:

the historical background of administrative litigation in Mexico dates back to the Law for the Settlement of Administrative Disputes [Ley para el Arreglo de lo contencioso administrativo] of 25 May 1853, which was influenced by contemporary French legislation, especially the notion of a Council of State - and which had caused a great uproar in the Mexican legal community, so that it was soon declared unconstitutional by the Mexican Supreme Court, which held that it violated the doctrine of Separation of Powers. ${ }^{42}$

In the latter half of the $19^{\text {th }}$ Century this debate was becoming obsolete in France and Germany because of the recognition that the administrative jurisdiction could be exercised if it were autonomous from the public administrative authorities even if such jurisdiction is not located in the Judiciary, on the model of the justice déléguée of 1872. According to Sommermann, the discussion that persisted in Continental Europe concerned the model of administrative jurisdiction to be adopted: either monist, typical of common law countries, or dualist, of French origin. It is the dualist version that ended up being successful due to the benefits of specialisation and to the elimination of its main drawback: the lack of independence. It was therefore the jurisdiction specialised in administrative law and autonomous from the public administrative authorities that prevailed in Continental Europe. ${ }^{43}$

41 In Mexico: José María Del Castillo Velasco, Ensayo sobre el Derecho administrativo mexicano [Essay on Mexican Administrative Law] V2 275 (1875); Teodosio Lares, Lecciones de derecho administrativo [Lessons on Administrative LaW] (1852); In Brazil: Castro, supra note 39.; Themístocles Brandão CaValcanti, Instituições de DiREITO ADMINISTRATIVO BRASILEIRo [INSTITUTIONS OF BRAZILIAN ADMINISTRATIVE LAW] Vol. $2748-59$ (2d ed. 1938).

42 Emilio Margáin Manautou, De lo contencioso administrativo: de anulación o de iLeGitimidad [On Admistrative Disputes: AnNulment or Illegality] $67-70\left(12^{\text {th }}\right.$ ed. 2004).

43 Karl-Peter Sommermann, O Desenvolvimento da Jurisdição Administrativa Alemã no Contexto Europeu, [The Development of the German Administrative Jurisdiction in the European Context], in R. Perlingeiro et AL., Código de Jurisdição administrativa: 
Taking the example of Brazil, the adoption of the unified judicial system by the Republican Constitution of 1891 is associated with a purely political choice in favour of US liberal constitutionalism, in opposition to the monarchic Brazilian institutions of the time, striking examples of which were the Imperial Council of State and administrative litigation under the system of justice retenue which, for obvious reasons, did not keep up with the evolution of European administrative law (justice déléguée): ${ }^{44}$ an autonomous administrative jurisdiction would be contrary to the fundamental principles of the Imperial Constitution of 1824, which remained in force until 1889.45

The doctrine of administrative law of the latter half of the $19^{\text {th }}$ Century continued to support the version originating in the French Council of State when they favoured backing the Brazilian Constitution of 1824, considering the Judiciary as a power intended for private law and the Executive as a power intended for public law. ${ }^{46}$ The reaction shown by the Republic Constituent Assembly of 1891 in adopting the unified judicial system is therefore understandable.

\section{The Unified Judicial System in Latin America IN THE $19^{\text {TH }}$ CENTURY AND Questions of GOVERNANCE}

It is true that in the late $19^{\text {th }}$ Century, there were no reasons for Latin America to distance itself from the European model of administrative justice; at the time, it seemed clear that the prohibition of exercise of jurisdiction by the Executive, as enshrined in the Constitution of Cadiz, would not prevent the Latin-American systems from keeping up with the evolution of the French model towards an autonomous administrative jurisdiction. The proof of that is what happened throughout Europe, especially in Spain and Portugal, and above all in Belgium, which abandoned the monist judicial system and where the Council of State exercised administrative jurisdiction without the possibility of appeal. ${ }^{47}$

o Modelo alemão [Code of the administrative JuRisdiction: the Germanm Model] Verwaltungsgerichtsordnung (VwGO) 13 (2009).

44 Castro, supra note 39; CAVAlCANTI, supra note 41. The U.S. influence on Brazil at the time may be measured by art. 386 of Decree No. 848 of 1890, which established U.S. law and common law precedents as a subsidiary source for Brazilian jurisprudence (Decreto No. 848, de 11 de Octubro de 1890 (Braz.)).

45 In the opinion of Ribas, clearly opposed to an autonomous administrative jurisdiction, "The creation of judges and courts devoted exclusively to trying such appeals would lead to the same disadvantages unless they could be frely appointed and removed by the government; otherwise, they would be new and costly springs in the already complex and costly administrative mechanism" (Antonio Joaquim Ribas, Direito adminisTRATIVO BRASILEIRo [BraZILIAN AdMINISTRATIVE LAW] 164 (1866).

46 See Visconde do Uruguai, Ensaios do direito administrativo [Essays on Administrative LAw] 29-36 (1862); RIBAS, supra note 45, at 143-65.

47 There are currently Councils of State with functions of administrative jurisdiction: France, the Netherlands, Belgium, Italy and Greece; cf. the judicial system of adminis- 
It fact, in early $19^{\text {th }}$ Century Latin America, the rise of an essentially judicial jurisdiction became apparent, which, however, gradually become more or less specialised as a sign of reconciliation with its European origin; starting from the early $20^{\text {th }}$ Century, certain Latin-American Constitutions began recognising the dualist judicial model of jurisdiction, with one jurisdiction specialised in administrative law and others with a non-judicial administrative jurisdiction.

The judicial system that prevailed in Latin America during the $19^{\text {th }}$ Century, after the independence movements between 1810 and 1831, was not accompanied by an invasive administrative jurisdiction; it tended to restrict itself to examining to disputes (contentieux) - closer to private law - in a judicial model more closely identified with the United States than with Continental Europe.

$19^{\text {th }}$-Century Latin America practically did not recognise any administrative jurisdiction in the judicial sphere, as in Belgian law (1831) and German law (1863); nor did it recognise any administrative jurisdiction in the Executive sphere, like French law (1872) and Spanish law (1874). Out of the 19 Latin-American countries of Iberian origin, only four deviated from the judicial system in the $19^{\text {th }}$ Century, opting instead for autonomous tribunals outside the structure of the Judiciary, although they subsequently back down from their decision: Bolivia (1861-1868, 1871-1878), Panama (1863-1904), Dominican Republic (1874-1880) and Colombia (1886-1914).

The system of unified jurisdiction over civil and administrative cases in Latin America offered no more than the French administrative litigation of the early $19^{\text {th }}$ Century, because the Executive itself settled the constant disputes about which - quite numerous - issues would be reserved exclusively for the public administrative authorities and immune from the Judiciary ("governmental" issues), as may be observed in the Chilean Constitution of 1833 and Ecuadoran Constitution of $1843 .{ }^{48}$ It was a judicial system that, in most LatinAmerican countries, had a restricted field of action, as occurred in Anglo-Saxon law; in that respect the system did not evolve much either in the United States or in the Latin-American countries that still make use of it.

trative jurisdiction with a specific supreme court in the following countries: Germany, Austria, Portugal, Luxemburg, Sweden, Finland, Czech Republic, Poland, Lithuania; there is a judicial system of administrative jurisdiction equipped with a supreme court with common administrative and civil jurisdiction in Spain, Switzerland, Slovenia, Hungary, Romania and Estonia; there is a unified judicial system (monist judicial system) in the United Kingdom, Ireland, Malta and Cyprus; see Michel Fromont, Droit administratif des États européens [Administrative LaW of the European States] 120 et seq. (2006); also see JACQUes ZiLLER, AdMINISTRATIONS COMPARÉES: LeS SYSTĖMES POLITico-administratifs de l'Europe des Douze [Compared Administrations: the Politicoadministrative Systems of the Europe of the Twelve] 438-45 (1993) (Fr.).

48 See Constitución Política de la República de Chile [C.P.] (1833) art. 104.5; Const. of ECUADOR (1843) art. 52.11. 


\section{The Specialization of Jurisdiction in Europe and the EMERGENCE of Administrative LaW.}

The fact is that the so-called system of undivided jurisdiction was a logical corollary of the lack of consolidation of administrative law; ${ }^{49}$ the administrative jurisdiction resolving administrative disputes - which had previously been easier to conceal among the "poderes de autotutela" [power to correct its own decisions and errors] - was a new activity assigned to supposedly autonomous state bodies, which coincides with what was understood to be administrative law.

Thus, the origin of the system of undivided jurisdiction or, according to Fromont, of the system of civil jurisdiction, ${ }^{50}$ is usually identified with Anglo-Saxon law: common law did not adopt administrative law until the late $19^{\text {th }}$ Century. Moreover, the $19^{\text {th }}$ Century Latin-American Constitutions reveal a model of judicial supervision of the public administrative authorities of the kind that prevailed in Europe before the French Revolution and, from that perspective, did not differ from the Constitution of Cadiz.

The Continental-European model of single-jurisdiction evolved as administrative law became more firmly established; the Judiciary became increasingly specialised, autonomous non-judicial bodies were created, such as the Conseil d'État of 1872, assigned specific powers to rule on cases of public interest; in practice, this helped limit the scope of administrative of actions that were considered at the time immune to the jurisdiction of the courts.

In this context, the regulatory gap left by the monist judicial system, with quasi jurisdictional immunity of the public administrative authorities, became more obvious as administrative law developed. ${ }^{51}$ That gap was subsequently filled in common law countries, however, by creating "administrative bodies invested with jurisdictional powers", according to Rivero, ${ }^{52}$ or "primary jurisdiction". ${ }^{53}$

49 According to RIVERo, supra note 6, at 126-127, "an undivided rule and an undivided judge were, for Dicey, the characteristic elements of the rule of law, and the system of administrative law and the principles on which such law is based are undeniably foreign to the spirit and traditions of the British institutions."

50 Fromont, supra note 47, at 135 et seq. (2006).

51 Rivero warns of the ideology unavowed Polizeistaat throughout the $20^{\text {th }}$ Century, in the United Kingdom, in the name of royal prerogatives, in the United States in the name of state sovereignty; and, in France, the theory of acts of government: Rivero, supra note 6 , at $159-60$.

$52 I d$. at 129 . Rivero clearly associates the weakening of the monist judicial system with the emergence of the "primary jurisdiction" within the Executive, which, in the United Kingdom, in 1948, reached the number of 207 types of specialised jurisdictions (id. at 136).

53 See Héctor A Mairal, Control judicial de la Administración Pública [Judicial Revew of Public Administrative Agenices] V2 714 (1984); also see Cassagne, supra note 9 , at 76 (2009). 


\section{E. The Evolution of the Unified Judicial System in the United States: InTERstate Commerce Commission (ICC) of 1887.}

The creation of the Interstate Commerce Commission (ICC) in 1887 in the United States marked the beginning of the administrative tribunals, a combination of the unified judicial model with adversarial proceedings in the area of public administrative authorities. ${ }^{54}$ However, that aspect of the U.S. system, which was not well established until the $20^{\text {th }}$ Century, was never considered by $19^{\text {th }}$ Century Latin America, for obvious reasons.

An irony of history is involved in the evolution of common law towards judicial review which brought an administrative jurisdiction into the heart of the Executive Branch ${ }^{55}$ by creating administrative tribunals whose judges, civil servants of the administrative authorities, have a certain degree of independence to resolve disputes, and their decisions are subject to partial review (cf. the Italian notion of delibazione) by the Judiciary. ${ }^{56}$ In Continental Europe, administrative law moved in the opposite direction: administrative jurisdiction exercised by the Executive is an exception, ${ }^{57}$ in which the elaboration of administrative decisions with the participation of the interested party is more similar to a procedimento (procedure) than to a processo (proceeding), since it does not clearly provide for guarantees of non-judicial due process. ${ }^{58}$

\section{F. Models of Administrative Jurisdiction in Latin America in the $19^{\text {TH }}$ AND $20^{\text {TH }}$ CENTURIES}

\section{Hybrid (Judicial and Non Judicial) Administrative Jurisdiction: Honduras, Brazil}

In Latin America, the only case of a hybrid model of administrative jurisdiction, as in common law countries, was provided for by the Constitution of

54 See Richard J. Pierce et al., Administrative LaW and Process 214 ( $4^{\text {th }}$ ed. 2004); see also MAIRAL, supra note 53, at Vol. 2714.

55 Speaking ironically, Rivero concluded that there is a dualist jurisdiction in the English judicial system (RIVERo, supra note 6, at 137).

56 See Asimow, supra note 9; Mairal, supra note 53, at 713.; Julio V. González García, El Alcance del Control Judicial de las Administraciones Públicas en los Estados Unidos de América [The Scope of Judicial Review of Public Administrative AuthoriTIES IN THE USA] 37 (1996).

57 Council of State in France, the Netherlands, Belgium, Italy and Greece) (Fromont, supra note 50, at 120 et seq.).

58 Under English law, the authorities were more closely tied to fundamental rights than to statutory law; on the contrary, under French law, the authorities were closely tied to statutory law than to fundamental rights (Maria da Glória Ferreira Pinto Dias Garcia, DA Justiça administrativa em Portugal: SUA origem E eVolução [Administrative Justice iN Portugal: its Origin AND Evolution] 333-34 (1994); see also Asimow, supra note 56. 
Honduras of $1965,{ }^{59}$ with the specialisation of an administrative chamber in the supreme court, ${ }^{60}$ as well as the creation of an Administrative Tribunal, which, pursuant to Article 210, did not form part of the Judiciary: the non-judicial tribunal exercised administrative jurisdiction and was subject to review by a supreme court through cassation. ${ }^{61}$

The Seventh Amendment of 1977 to the Brazilian Constitution of 1969 provided for the possibility of legislators instituting non-judicial administrative litigation which would be subject to judicial supervision, as in contemporary U.S. judicial review, but it never became well established in practice. $^{62}$

\section{Non-Judicial Administrative Jurisdiction: Bolivia, Panama, Dominican Republic, Colombia, Guatemala, Ecuador, Uruguay, Mexico}

In the $19^{\text {th }}$ Century, as mentioned above, Bolivia (1861-1868, 1871-1878), Panama (1863-1904), the Dominican Republic (1874-1880) and Colombia (1886-1914) experimented with an administrative tribunal that was autonomous from the Judiciary, and, in the $20^{\text {th }}$ Century, it was the turn of Guatemala (1927-1945), Ecuador (1929-1979) and, once again, Panama (1945-1956).

Bolivian administrative law recognised a Council of State, conceived of as a body outside the Judiciary, accompanied by Supreme Administrative Court, which exercised administrative jurisdiction (justice deleguée), during the brief effective period of the Constitution of $1861,{ }^{63}$ interrupted by the Constitution of 1868 , and then immediately returned to the system of the

59 Const. of Honduras (1965) art. 210 (c). This Constitution was repealed by the Constitution of 1982, which restored the judicial system of monist jurisdiction that was traditional in Honduran constitutional law (Honduran Constitutions of 1825, 1831, 1839, 1848, 1865, 1873, 1880, 1894, 1904, 1924, 1936 and 1957).

60 Const. of Honduras (1965) art. 229.

${ }_{61}$ Const. of Honduras (1965) art. 210; Const. of Honduras (1965) art. 229.

62 See Francisco Mauro Dias, Contencioso Administrativo nos estados para questão de pessoal [Administrative Litigation in the States for Personal Matters], $8^{\text {th }}$ National Convention of State Prosecutors, Rio de Janeiro: Government Attorney's Office of the State of Rio de Janeiro, 1979. Anais. Regarding Amendment 7/77, I should make amends by correcting an incorrect note in one of my previous articles (Perlingeiro, supra note 3, at 293-331 (2015)) where I said that the Constitutional Amendment 7/77 concerned a dispute challenging the Judiciary; in reality, it concerned just the opposite: a dispute submitted to the Judiciary (Ricardo Perlingeiro, Execução contra a Fazenda Pública [Enforcement Measures against the Public Authorities] 47 (1998)); See Ada Pellegrini Grinover, O Contencioso Administrativo na Emenda 7/77 [Administrative Litigation in Amendment 7/77], 10 Revista da Procuradoria Geral do Estado de São Paulo 247 et seq.

63 Const. of Bolivia (1861) art. 41.6; Const. of Bolivia (1861) art. 42. 
period between the Constitutions of 1871 and $1878,{ }^{64}$ until the effective date of the Constitution of 1878, when jurisdiction over administrative disputes was assigned to the Supreme Court. ${ }^{65}$

In Panama, the Corte de Estado was established by the Constitution of $1863^{66}$, which was maintained by the Constitutions of $1865^{67}, 1868^{68}$, $1870^{69}, 1873^{70}$, and the Corte Superior de Estado, with the Constitution of $1875^{71}$, until the advent of the Constitution of 1904. Later on, in 1945, an administrative tribunal autonomous from the Executive and Judiciary was created, ${ }^{72}$ which continued to exist until the Constitutional Reform of 1956.

The Dominican Republic formed a non-judicial administrative jurisdiction within the Legislative Branch, during the effective period of the Constitutions of $1874^{73}, 1878^{74}$ and $1879^{75}$. The Colombian Constitution of 1886 included among the powers of the Council of State, which at the time was a non-judicial body, jurisdiction to rule on administrative litigation, as an undivided level of authority or on the appellate level, in accordance with the law, and also authorised legislators to create tribunals with jurisdiction over administrative disputes involving questions specific to the Departamentos. ${ }^{76}$

Starting from the constitutional reforms in Guatemala of $1927^{77}$ and $1935^{78}$, a distinction was drawn between the cases (conflicts) to which the public administrative authorities are a party, maintaining the authority of the ordinary judges, and exclusively administrative cases, which would be

64 Const. of Bolivia (1871) art. 59.8; Const. of Bolivia (1871) art. 59.9; Const. of BoLIVIA (1871) art. 79.

65 Const. of Bolivia (1878) art. 111.5.

66 Const. of Panama (1863) art. 71; Const. of Panama (1863) art. 72.

67 Const. of Panama (1865) arts. 83-87.

68 Const. of Panama (1868) arts. 94-99.

Const. of Panama (1870) arts. 93-98.

Const. of Panama (1873) arts. 97-102.

Const. of Panama (1875) arts. 82-87.

72 Art. $8^{\circ}$ of Legislative Decree No. 4 of 1945; Arturo Hoyos, El Derecho ContencioSO-ADMINISTRATIVO EN PANAMA (1903-2005): UNA INTRODUCCIÓN HISTÓRICA DE DERECHO comparado y jurisprudencial [The LaW of Administrative Disputes in Panama (19032005): A Historical Introduction from the Perspective of Comparative LaW and Case LAW] 16 (2005).

73 Const. of Dominican Republic (1874) art. 71.7.

74 Const. of Dominican Republic (1878) art. 22.8.

75 Const. of Dominican Republic (1879) art. 22.8.

76 Const. of Colombia (1886) art. 141.3; Const. of Colombia (1886) art. 164.

77 Guatemalan Constitutional Amendment (1927) art. 41.3, which reworded art. 85 of the amended constitution.

78 Guatemalan Constitutional Amendment (1935) art.6, which reworded art. 17 of the Constitution, and art. 23, which changed the wording of art. 85 of the amended constitution. 
under the authority of the Administrative Tribunal- a non-judicial body with an undivided level of court.

The Ecuadoran Constitution of 1929 established the authority of the Council of State - a non-judicial body - to provide the jurisdiction over administrative disputes on an undivided level of $\operatorname{court}^{79}$; the 1945 Constitution provided for the Tribunal de Garantias Constitutional, likewise outside the Judiciary, exercising jurisdiction over administrative disputes on an undivided level of $\operatorname{court}^{80}$; and, finally, the terminology of the Constitution of 1967 referred to a judicial jurisdiction and the jurisdiction of the fiscal and administrative tribunals headquartered in Quito, conveying the idea of a non-judicial administrative jurisdiction on an undivided level of court. ${ }^{81}$

In modern-day Latin America, there are only two examples of nonjudicial administrative jurisdiction: Uruguay, with its Tribunal de lo Contencioso Administrativo, since 1934, and Mexico, with its Tribunal Federal de Justicia Fiscal y Administrativa, created in 1937, inspired by the Conseil d'État of $1872 .{ }^{82}$

The Uruguayan Constitution of $1934^{83}$ established an Administrative Tribunal [Tribunal do Contencioso Administrativo] a body that was separate from the Judicial Branch, with the function of exercising administrative jurisdiction on an undivided level of court. It became a tradition of Uruguayan constitutional law, providing rules of procedure for administrative litigation, ${ }^{84}$ including the scope of individual claims and the jurisdiction of the ordinary courts over damage claims ${ }^{85}$. That same clause is maintained in the Constitutions of $1942^{86}, 1952^{87}$ and $1967^{88}$.

According to Article 73 XXIX of current Mexican Constitution of 1917, after subsequently (most recently on 4 December 2006), the Legislative Branch is authorised:

to issue laws establishing administrative tribunal that are granted full autonomy to render their decisions and that are in charge of settling disputes arising between individuals and the federal administrative authorities, and to impose penalties on public servants for such adminis-

\footnotetext{
79 Const. of Ecuador (1929) art. 117.2; Const. of Ecuador (1929) art. 10.

80 Const. of Ecuador (1945) art. 160.8.

81 Const. of Ecuador (1967) art. 28.15 ch. 1-2; Const. of Ecuador (1967) art. 213.

82 Héctor Fix-Zamudo, Tres Instituciones Francesas Revolucionarias y el Derecho Constitucional Mexicano [Three Revolutionary French Institutions and Mexican Const.al Law] 82 (1991).

83 Const. of Uruguay (1934) art. 271; see Augusto Durán Martínez, Contencioso Administrative [Administrative Disputes] 15, 21 et seq. (2007).

84 Const. of Uruguay (1934) arts. 273-75.

85 Const. of Uruguay (1934) art. 275.2.

86 Const. of Uruguay (1942) arts. 268-74.

87 Const. of Uruguay (1952) art. 221; Const. of Uruguay (1952) arts. 307-21.

88 Const. of Uruguay (1967) arts. 307-21.
} 
trative offences as are prescribed by law, establishing the rules for their organization, operations, procedures and appeals against their decisions.

The Mexican Administrative Tribunal for Tax Matters (Tribunal Federal Fiscal Administrativo] was created by the Law of 27 August 1936 and is still in force today. The Constitution of 1917 authorizes the creation of similar tribunals by the Mexican States and the Federal District ${ }^{89}$. Thus, Mexican administrative law has co-existed with autonomous non-judicial administrative tribunals since 1937. Despite their legal nature, the administrative tribunals are outside the structure of the Judiciary and considered to be autonomous bodies under Article 94 of the Constitution of 1917 and the procedure of amparo against judicial decisions is provided by Article 107 IV and $\mathrm{V} \mathrm{b.} .^{90}$ In fact, the model of undivided jurisdiction has never ceased to exist in Mexico; it is not used, however, whenever the law has established a non-judicial administrative tribunal that is "autonomous", to use the terminology of the Constitution. ${ }^{91}$

In 1984, the President of the Federal Republic of Brazil sent a message to the National Congress proposing the creation of an administrative (nonjudicial) tribunal for litigation which, in reality, implied solely non-judicial administrative jurisdiction without the possibility of subsequent judicial review. The proposal was not approved however, in light of the severe criticism from the legal community. ${ }^{92}$

\section{Dualist Judicial Jurisdiction: Colombia, Nicaragua, Panama, Ecuador, Guatemala, Dominican Republic}

The dualist system of judicial jurisdiction with a specific supreme court, as is currently found in Germany and Portugal, was incorporated into the territory of Latin America only by Colombia, where it has been in force since 1914. Despite its name of Consejo de Estado and the fact that its jurisdictional functions are situated alongside its consultative functions, the Supreme Court of the Colombian administrative jurisdiction is a body of the Judicial Branch.

89 Arts. $116 \mathrm{~V}$ and 122 Base Quinta of the Mexican Constitution of 1917.

90 Const. of Mexico (1917) art. 94; Const. of Mexico (1917) art. 107 V; Const. of MexICO (1917) art. $107 \mathrm{~V} \mathrm{~b}$; On the nature of the Tribunal Federal Fiscal Administrativo [Federal Administrative Tax Court], see Emilio Margáin Manautou, De lo Contencioso Administrativo: de Anulación o de Ilegitimidad [On Admistrative Disputes: AnNULMENT OR ILLEGALITY] 2 et seq. (2009).

91 On judicial review of the public administrative authorities in general, see Jorge Fernández Ruiz, Panorama General del Derecho Administrativo Mexicano [General Overview of Mexican Administrative Law], in Santiago González-Varas Ibáñnez, El DERECHO ADMINISTRATIVO IBEROAMERICANO [IBERO-AMERICAN AdMINISTRATIVE LAW] 462 63 (2005).

92 Ricardo Perlingeiro, Execução contra a Fazenda Pública [Enforcement Measures against the Public Administrative Authorities] 48 (1998). 
The Legislative Act No. 3 (Constitutional Amendment) of 1910 modified Title XV of the Colombian Constitution of 1886, on the administration of justice ${ }^{93}$, and established an institution specialising in jurisdiction over administrative disputes. The Reform Act (Constitutional Amendment) of $1914^{94}$ assigned to the Council of State the function of Supreme Court of administrative litigation. Finally, in the Constitution of 1991, the Council of State is maintained as a body of the Judicial Branch and its functions included acting as Supreme Court of jurisdiction over administrative disputes. $^{95}$

A dualist system of judicial jurisdiction with an undivided Supreme Court was established constitutionally in the following countries of Latin America: Nicaragua, in the periods from 1939 to 1948, with courts and judges for administrative disputes, ${ }^{96}$ and from 1974 to 1979 , with the Administrative Court [Tribunal do Contencioso Administrativo ${ }^{1},{ }^{7}$ which, however, were never implemented by the legislator; ${ }^{98}$ Panama, from 1941 to 1945 , with the juicios de lo contencioso-administrativo [courts to rule on disputes under administrative law]; ${ }^{99}$ Ecuador, from 1979 to 1992, with the Administrative Court, on an undivided level of court; ${ }^{100}$ Guatemala, starting from 1945, with the Administrative Court; ${ }^{101}$ and the Dominican Republic, starting from $2010^{102}$.

4. Monist Judicial Jurisdiction (uninterrupted period): Chile, Argentina, Venezuela, Paraguay, México, Costa Rica, Peru, El Salvador, Cuba, Brazil

The monist judicial system was the only that all the Latin-American countries had an opportunity to experience at a certain moment of their constitutional history. Some of them did so uninterruptedly from the start of the effective period of their Republican Constitution, as occurred in Chile, Argentina and Venezuela since 1811; in Paraguay since 1813, México, 1818; Costa Rica, 1821; Peru, 1823; El Salvador, 1824; Cuba, 1869; and Brazil, 1891.

93 Legislative Act 3 (Constitutional Amendment) of 1910, amending Title XV of the Colombian Constitution of 1886 (art. 42).

94 Ato Reformatório (Constitutional Amendment) (1914) art. 6.3 (Colom.).

95 Const. of Colombia (1991) art. 231.

96 Const. of Nicaragua (1939) art. 243.

97 Arts. 280, 290 and 303 Const. of Nicaragua (1974) art. 280; Const. of Nicaragua (1974) art. 290; Const. of Nicaragua (1974) art. 303.

98 See Republica De Nicaragua, Sala de lo Contencioso Administrativo. Antecedentes y Creación de la Sala de lo Contencioso Administrativo [Administrative Law Division of the Courts: History and Creation of Administrative Litigation].

99 Const. of Panama (1941) arts. 190-92.

100 Const. of Ecuador (1979) art. 98 (y).

101 Const. of Guatemala (1945) art. 164; Const. of Guatemala (1956) arts. 193 -94; Const. of Guatemala (1965) art. 255; Const. of Guatemala (1985) art. 221.

102 Const. of the Dominican Republic (2010) arts. 164-65. 
The history of the Chilean Judiciary is characterised by a judicial system of monist jurisdiction in the Constitutions of 1811, 1818, 1822, 1823, $1828,1833,1925$ and $1980 .{ }^{103}$ In Argentina, in the absence of an explicit reference to a specialised court in its constitutions, it must be concluded that Argentine law established a monist judicial system, as can be observed in the Constitutions of 1811, 1813, 1815, 1816, 1817, 1819, 1826, 1856, 1860, 1942 and 1994. Venezuelan law adopted a monist judicial system in the Constitutions of 1811, 1819, 1821, 1830, 1858, 1874, 1901, 1909, 1931, 1945, 1947, 1953, 1961 and 1999. ${ }^{104}$

Paraguay adopted the monist judicial system. ${ }^{105}$ Although the Charters of 1813 and 1844 do not lay down any rules in that respect, starting from the Constitution of $1870,{ }^{106}$ a jurisdiction for administrative disputes was expressly established as an exclusive attribute of the Judiciary, to the exclusion of the Executive. The same rule was incorporated into the subsequent Constitutions, which also authorised the Congress to legislate on administrative disputes: Constitution of $1940 ;{ }^{107}$ Constitution of $1967 ;^{108}$ Constitution of $1992^{109}$.

In Mexico, the judicial system of monist jurisdiction has been the framework up to the present day: it was implicitly established in the Constitutions of $1818,1824,1836,1857$ and $1917 .{ }^{110}$ In Costa Rican constitutional law, there was not an undivided exception to the judicial system of monist jurisdiction throughout the effective period of its 14 Constitutions: 1821, 1823 (Constitutions of 17 March 1823 and 16 May 1823), 1824, 1825 (with the amendment of 1835), 1844, 1847, 1848, 1859, 1869, 1871, 1917, and 1949.

Peruvian constitutional law anchored the judicial system of monist jurisdiction from its first Constitution, in 1823, and it was maintained by the Constitutions of 1828, 1834, 1837, 1839, 1856, 1860, 1867, 1920, 1933,

${ }^{103}$ See Alejandro Vergara Blanco, Panorama General del Derecho Administrativo Chileno [General Overview of Chilean Administrative Law], in, EL DERECHO ADMINISTRATIVO iberoamericano [Ibero-American Administrative Law] 159-61 (Santiago GonzálezVaras Ibáñnez ed. 2005).

104 See Allan R. Brewer-Carrías, Instituiciones políticas y constitucionales [Political AND Const.al institutions] vol. 7. La JUSTICIA CONTENCIOSO ADMinistrative [AdMinStRATIVE JUSTiCE] 21 et seq. (1997).

${ }^{105}$ See Luis Enrique Chase Plate, La Justicia Constitucional y la Justicia Administrative [Constitutional Justice and Administrative Justice in Derecho Administrativo IberoAmericano [IBero-American Administrative Law] vol.2 1212-13 (Víctor Hernández-Mendible ed. 2007).

106 Const. of Paraguay (1870) art. 117.

107 Const. of Paraguay (1940) art. 76.12; Const. of Paraguay (1940) art. 87.

108 Const. of Paraguay (1967) art. 149; Const. of Paraguay (1967) art. 199.

109 Const. of Paraguay (1992) art. 248.

110 See Jorge Fernández Ruiz, Panorama General del Derecho Administrativo Mexicano [General Overview of Mexican Administrative Law], in Santiago González-Varas Ibáñnez ed., supra note 103, at 462-63. 
1979 and 1993; it should be pointed out the Constitution of 1867 called for the creation by law of Tribunales contencioso-administrativos [courts for administrative disputes]. ${ }^{111}$

The Constitutions of El Salvador of 1824, 1841, 1864, 1871, 1872, 1883 and 1886 ommitted any mention of administrative litigation, which resulted in a judicial system of monist jurisdiction; starting from the Constitution of $1939^{112}$, the constituent assemblies authorised the legislators to organise a jurisdiction linked to the Judiciary that included administrative matters: Constitutions of $1944^{113}, 1950^{114}, 1962^{115}$ and $1983^{116}$.

In Cuba, only two of its Constitutions expressly refer to the jurisdiction over administrative disputes as a function of the ordinary courts (Constitutions of $1934^{117}$ and of $1935^{118}$ ); the others failed to mention any body as having the authority to rule on such conflicts, so that Cuba, too, is considered to have established the judicial system of monist jurisdiction: Constitutions of 1869, 1878, 1895, 1897, 1901, 1940, 1952, 1959, 1976 (with the amendment of 1992 and 2002). In Brazil, the Constitutions that followed the proclamation of the Republic, those of 1891, 1934, 1937, 1945, 1967, 1969 and 1988, all adopted the judicial system of monist jurisdiction.

\section{Monist Judicial Jurisdiction (Limited Period): Colombia, Guatemala, Dominican Republic}

Colombia (1821-1886), Guatemala (1824-1927) and the Dominican Republic (1854-1874, 1880-2010) experienced the undivided judicial system for a limited period of time.

The Colombian Constitutions of 1821, 1830, 1832, 1843, 1853, 1858 and 1863 do not refer to administrative litigation, which suggests that the Judiciary, in that period, exercised an undivided jurisdiction, including, within its area of authority, jurisdiction over conflicts of public interest involving the administrative authorities. The Constitution of $1830,{ }^{119}$ in particular, established the authority of the High Court of Justice to try any case involving contracts or transactions with the Executive Branch, which confirms the existence of a judicial system of monist jurisdiction that is inclined to settle private law disputes with public administrative authorities, while excluding from judicial evaluation matters of administrative law,

111 Ramón A. Huapaya Tapia, Tratado del processo contencioso administrative [Treatise on Administrative Procedure] 335 (2006).

112 Const. of El Salvador (1939) art. 77.17.

113 Const. of El Salvador (1944) art. 75.17.

114 Const. of El Salvador (1950) art. 46.13.

115 Const. of El Salvador (1962) art. 47.13.

116 Const. of El Salvador (1983) art. 131.31.

117 Const. of Cuba (1934) art. 80.

118 Const. of Cuba (1935) art 86.

119 Const. of Colombia (1830) art. 110.1. 
which are considered to fall exclusively within the scope of the Executive. That rule was maintained with minor alterations in the Constitutions of $1832,{ }^{120} 1858^{121}$ and $1863 .{ }^{122}$

In Guatemala, the Constitutions of $1824,1825,1879$ and 1921 do not establish any specific body with the authority to rule on conflicts involving the administrative authorities; it is therefore presumed to have a system of undivided jurisdiction system; the Constitution of 1839 refers to administrative litigation matters as one of the subject areas under the authority of the courts. ${ }^{123}$

In the Dominican Republic, the monist judicial jurisdiction, generally concentrated in the Supreme Court, predominated through much of its constitutional history (Constitutions of 27 February 1854, ${ }^{124} 10$ December $1854,{ }^{125} 1858,1865,{ }^{126} 1866,{ }^{127} 1872,{ }^{128} 1877,1880,{ }^{129} 1881,{ }^{130} 1887,,^{131}$ 1884, ${ }^{132} 1896,{ }^{133} 1906,{ }^{134} 1908,1924,1934,1942,1955,1960,1961$, 1963, 1966, 1994 and 2002); the only exception was in the effective period of the Constitutions of $1874,{ }^{135} 1878,{ }^{136}$ and $1879,{ }^{137}$ with a non-judicial administrative jurisdiction, and after the Constitution of $2010,{ }^{138}$ with a dualist judicial jurisdiction.

6. Monist Judicial Jurisdiction (Intermittent Periods): Nicaragua, Honduras, Ecuador, Panama, Bolivia

Another group of countries initiated the Republic with the monist judicial system and then searched for a different model of administrative jurisdiction, subsequently returning to the original system: Nicaragua (1884-1939,

\footnotetext{
120 Const. of Colombia (1832) art. 131.3.

121 Const. of Colombia (1858) art. 49.11.

122 Const. of Colombia (1863) art. 71.8.

123 Const. of Guatemala (1839) art. 32.1.

124 Const. of Dominican Republic, February 27 1854, art. 100.6.

125 Const. of Dominican Republic, December 10 1854, art. 45.6.

126 Const. of Dominican Republic (1865) art. 87.5.

127 Const. of Dominican Republic (1866) art. 70.7.

128 Const. of Dominican Republic (1872) art. 45.6.

129 Const. of Dominican Republic (1880) art. 67.11.

130 Const. of Dominican Republic (1881) art. 70.11.

131 Const. of Dominican Republic (1887) art. 69.10.

132 Const. of Dominican Republic (1884) art 134.8.

133 Const. of Dominican Republic (1896) art. 69.10.

134 Const. of Dominican Republic (1906) art. 66.10.

135 Const. of Dominican Republic (1874) art. 71.7.

136 Const. of Dominican Republic (1878) art. 22.8.

137 Const. of Dominican Republic (1879) art. 22.8.

138 Const. of Dominican Republic (2010) arts. 164-67.
} 
1948-1974, 1979-), Honduras (1825-1965, 1982-), Ecuador (1830-1929, 1992-), Panama (1841-1863, 1904-) and Bolivia (1826-1861, 1878-). ${ }^{139}$

In Nicaragua, the monist judicial system was in effect in the Constitutions of the years $1884,{ }^{140} 1826,1838,1842,1848,1854,1858,1893$ (until the advent of the Constitution of 1898), 1905, 1911, 1912, 1913 (until the advent of the Constitution of 1939), 1948, 1950 (until the advent of the Constitution of 1974), 1979, 1987, 1995 (Constitutional Amendment, providing for a specialisation in administrative litigation within the Supreme Court) ${ }^{141}$ and 2014 (Constitutional Amendment, granting the Supreme Court jurisdiction over administrative litigation) ${ }^{142}$.

The judicial system of monist jurisdiction was in force in the Constitutions of Honduras of 1825, 1831, 1839, 1848, 1865, 1873, 1880, 1894, 1904, 1924, 1936, 1957 and 1982, which were silent about administrative litigation; the only exception was the Constitution of 1965, which instituted a court that was autonomous vis-à-vis the Judiciary. ${ }^{143}$

In Ecuador, the Constitutions of 1830, 1835, 1843, 1851, 1852, 1861, $1869,1878,1884,1897$ and 1906 provided general rules about the Judiciary but without any mention of the state bodies responsible for administrative dispute resolution. Such silence was no doubt motivated by the desire of the constituent assembly to set up a judicial system of monist jurisdiction to resolve issues involving administrative authorities a system which remained in effect until the advent of the Constitution of 1929.

The Constitutional Amendment of 1992 established that administrative litigation is to be ruled on by a judicial body to be defined by law and that the Supreme Court will have the authority to deliver a final binding judgement in case of appeals from lower courts, as confirmed by the Constitution of $1998^{144}$ : the monist judicial system was re-established in Ecuador in light of the Constitution. With the same orientation, the Constitution of 2008 stipulated that the acts of public powers could be challenged in

139 See José Mario Serrate Paz, Análisis y Evaluación del Proyecto de Ley del Proceso Contencioso Administrativo en Bolivia [Analysis and Evaluation of the Draft Law of Administrative Proceedings in Bolivia], in Hernández-Mendible, supra note 105, at 1233 (2007).

${ }^{140}$ A constitution according to which it was legal to bring proceedings against the Executive (Constitution of Nicaragua (1884) art. 191).

141 Const. of Nicaragua (1884), art. 163, Const. Of Nicaragua (1987) art. 163 as amended by the constitutional amendment of 1995 .

142 Const. of Nicaragua (1884), art. 163, Const. of Nicaragua (1987) art. 163 as amended by the constitutional amendment of 2014 .

See, generally, Republica De Nicaragua. Sala de lo Contencioso Administrativo. Antecedentes y Creación de la Sala de lo Contencioso Administrativo [Administrative Law Division of the Courts: History and Creation of Administrative Litigation] available at: $<$ http://bit.ly/15XqPMX>.

143 Const. of Honduras (1965), art. 210(c).

144 Const. of Ecuador (1998), art. 196; art. 197. 
administrative and judicial fora, and prohibited the Executive and Legislative Branches from exercising jurisdictional functions. ${ }^{145}$

In Panama, the judicial system of monist jurisdiction prevailed in the period from 1841 to 1863 (Constitutions of $1841^{146}, 1853$ and 1855), from 1904 to 1941 (Constitution of 1904, until the advent of the Constitution of 1941); starting from the Constitutional Amendment of $1956,{ }^{147}$ jurisdiction over administrative litigation was indicated as one of the functions of the Supreme Court (Constitution of $1972^{148}$ and the Amendments of $1983^{149}$ and $2004^{150}$.

In Bolivia, administrative jurisdiction was exercised by a unified judicial system throughout most of its constitutional history, during the effective periods of the Constitutions of 1826, 1831, 1834, 1839, 1843, 1851, 1868, 1878, 1880, 1938, 1945, 1947, 1967, 1994, 2004, 2008 and 2009. A system of non-judicial administrative jurisdiction was found only under the Constitutions of 1868 and 1871. In the Constitution of 2004, express reference is made to the judicial unity of the system and the function of resolving administrative litigation and disputes is assigned to the courts, judges and Supreme Court. ${ }^{151}$

\section{Monist Judicial Jurisdiction (Currently in Effect and with Specialised} Bodies): Chile, Argentina, Venezuela, Paraguay, Mexico, Costa Rica, Peru, El Salvador, Cuba, Bolivia, Brazil, Panama, Nicaragua, Honduras and Ecuador

In general, in the countries that maintained the monist judicial system (Chile, Argentina, Venezuela, Paraguay, Mexico, Costa Rica, Peru, El Salvador, Cuba, Bolivia, Brazil, Panama, Nicaragua, Honduras and Ecuador), it developed with a certain level of specialisation, both in the level of court (trial and appellate levels) and a special section within the Supreme Court. Such is the example of Chile, whose Constitution of $1925^{152}$ called for the creation by law of administrative courts in the Judicial Branch, and whose Constitution of $1980^{153}$ directed the courts created by law to evaluate individual claims against the administrative authorities, despite the fact that, in both cases, it was merely an attempt at constitutional norm, which never became a reality. ${ }^{154}$

145 Const.of Ecuador (2008), art. 188.3; art. 173.

146 Const. of Panamá (1841), art. 109.5.

147 Legislative Act 2 of Oct. 25, 1956. See Hoyos, supra note 72.

148 Const. of PANAmá (1972), art. 188.2.

149 Const. of Panamá (1972), art. 203.2 (with the Constitutional Amendment of 1983).

${ }^{150}$ Const. of Panamá (1972), art. 206.2 (with the Constitutional Amendment of 2004).

151 Const of Bolivia (2004), arts. 116.3 \& $118.4 \& 7$.

152 Const. of Chile, (1925), art. 87.

153 Const.of Chile 1925, art. 38.2.

154 See Alejandro Vergara Blanco, Panorama General del Derecho Administrativo Chileno [General Overview of Chilean Administrative Law], El Derecho administrativo IBEROAMERICANO [Ibero-American Administrative Law] 2005, at 159-61. 
We could also mention Argentina, with the administrative justice of the Province of Buenos Aires, which provides for special sections in courts of the first and second instances ${ }^{155}$, and Brazil, currently with the Federal Justice System, with authority to rule on administrative cases of interest to the Federal Government, the state courts of first instance (courts of the State Treasury [Fazenda Pública] and Executable Tax Debt [Dívida Ativa]) and the specialised public-law divisions of the Supreme Court (Superior Tribunal de Justiça). ${ }^{156}$

Other examples include Venezuela, with the Constitutions of 1961 and 1999, granting administrative jurisdiction to the courts defined by law; ${ }^{157}$ Nicaragua, in the periods of 1898 to 1905 , with the federal courts, ${ }^{158}$ from 1948 to 1979 , with the courts and judges of the Republic, ${ }^{159}$ and the Constitution of 1987, with the Amendments of 1995 and 2014 (Constitutional Amendment establishing a special section for administrative litigation in the Supreme Court), ${ }^{160}$ and Costa Rica, with administrative courts, in accordance with the Constitution of $1949 .{ }^{161}$

\section{H. Developmental and Comparative Framework of the Autonomous Administrative JuRISDiction Under the LATIN American Constitutions}

The evolutionary pattern in Latin America in the $19^{\text {th }}$ and $20^{\text {th }}$ Centuries may be displayed according to the basis of the four models of administrative jurisdiction identified.

155 See Héctor A. Mairal, Control Judicial de la Administración Pública [Judicial Review of Public Administrative Authorities], vol.1, 1984, at 124-26.

156 Const. of BRAZIL (1988), art. 109 §I; see also Internal Regulations of the Superior Court of Justice, at $\S 1^{\circ}$; Internal Regulations of the Federal Regional Court of the $2 \mathrm{~d}$ Region, at arts. $2^{\circ}$ III, § 4 ${ }^{\circ}$, \& 13 III; Lei de Organização e Divisão Judiciárias [Judicial Division and Organization Act of the State of Rio de Janeiro], State Law 6.956/2015, at arts. 44 and 45 III.

157 Constitución de la República Bolivariana de Venezuela 1979, art. 206; see also Constitución de la República Bolivariana de Venezuela 1999, art. 259; Allan R. Brewer-Carrías, Instituiciones Políticas y Constitucionales. [Political and ConstiTUTIONAL INSTITUTIONS] vol.7, 12-14, 19 (1997).

158 Const. of Nicaragua (1898), art. 128; see also The Federal Courts of the Constitution of 1898 (which were to reappear later under the name of Courts of the Republic [from 1948 to 1979] do not consist in a specialised jurisdiction but rather in judicial bodies having jurisdiction of cases of federal interest, on the model of what always happened in Brazilian constitutional law from 1891).

159 Const. of Nicaragua (1948), art. 217; see also Const. of Nicaragua (1950), art. 233; Const. of Nicaragua (1974), art. 311.

${ }^{160}$ Const. of Nicaragua (1987), art. 163; see also Const. of Nicaragua (2014), art. 163. (with the Constitutional Amendment of 1995).

161 Const. of Costa Rica (1949), art. 173.2; see also Enrique Rojas Franco, Comentarios al Código Procesal Contencioso Administrativo [Comments on the Code of ProceDURe of Administrative Litigation] 18 (2008). 


\section{EVOLUTION OF THE AUTONOMOUS ADMINISTRATIVE JURISDIC- TION IN THE LATIN-AMERICAN CONSTITUTIONS}

\section{JUDICIAL JURISDICTION}

Monist/unified-jurisdiction (body or court in a non-specialised judicial structure, with a constitutional basis)

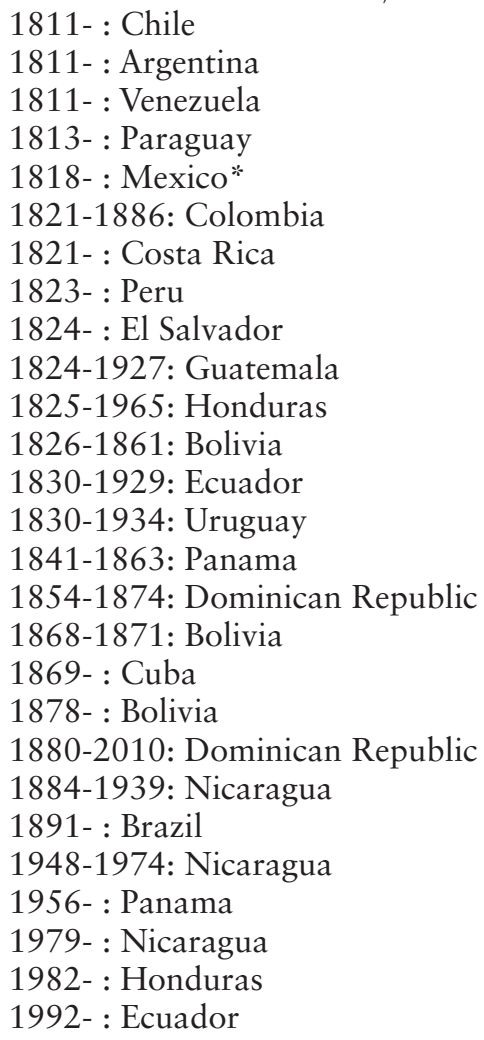

Dualist jurisdiction (body or court in a specialised judicial structure with a constitutional basis)

Single Supreme Court (body or court in a specialised structure and subject to a Supreme Court of another structure)

1939-1948: Nicaragua

1941-1945: Panama

1979-1992: Ecuador

1945- : Guatemala

1974-1979: Nicaragua

2010- : Dominican Republic
Administrative Supreme Court (body or court and a Supreme Court in a specialised structure)

1914- : Colombia

\section{NON-JUDICIAL JURISDICTION}

Autonomous (body or court in a nonjudicial structure, with a constitutional basis and autonomous from the challenged authority)
1861-1868: Bolivia
1863-1904: Panama
1871-1878: Bolivia
1874-1880: Dominican Republic
1886-1914: Colombia
1927-1945: Guatemala
1929-1979: Ecuador
1934- : Uruguay
1937- : Mexico*
1945-1956: Panama

Non-autonomous (body or court in a non-judicial structure, with a constitutional basis, and non-autonomous visà-vis the challenged authority)

\section{HYBRID JURISDICTION (NON-JUDICIAL AND JUDI- CIAL)}

Autonomous (body or court in a nonjudicial structure, with a constitutional basis and autonomous from the challenged authority and subject to a judicial body or court) 1965-1982: Honduras

Non-autonomous (body or court in a non-judicial structure, with a constitutional basis, non-autonomous vis-à-vis the challenged authority and subject to a judicial body or court) 


\title{
III. Administrative Decisions Preceded by Due PROCESS OF LAW
}

\author{
A. Signs of U.S. Due Process of LaW in Latin America: The $5^{\text {th }}$ \\ (1791) AND 14 ${ }^{\mathrm{TH}}$ (1868) AMENDMENTS OF THE U.S.CONSTITUTION
}

The predominance of the monist judicial system is not the only sign of U.S. influence to be found in the administrative justice systems of Latin-American countries; the expression due process of law, which was first provided for in the United States by the Bill of Rights (1791 Amendment to the U.S. Constitution), started to become incorporated in a number of different Latin-American constitutions and laws in the latter half of the $20^{\text {th }}$ Century. Such is the case with Argentina, Bolivia, Brazil, Chile, Colombia, Ecuador, Guatemala, Mexico, Nicaragua, Peru, the Dominican Republic, Uruguay and Venezuela.

However, due process of law, which has been described in common law countries as procedural guarantees prior to administrative decisions that impose restrictions on individual rights, ${ }^{162}$ has taken on a quite different form in Latin America.

The Fifth Amendment of 1791 to the U.S. Constitution reads as follows: ${ }^{163}$

no person shall be held to answer for a capital, or otherwise infamous crime, unless on a presentment or indictment of a Grand Jury, except in cases arising in the land or naval forces, or in the Militia, when in actual service in time of War or public danger; nor shall any person be subject for the same offence to be twice put in jeopardy of life or limb; nor shall be compelled in any criminal case to be a witness against himself, nor be deprived of life, liberty, or property, without due process of law; nor shall private property be taken for public use, without just compensation. ${ }^{164}$

The Fourteenth Amendment of 1868 has a similar orientation in Section 1:

[...] No State shall make or enforce any law which shall abridge the privileges or immunities of citizens of the United States; nor shall any State deprive any person of life, liberty, or property, without due process of law; nor deny to any person within its jurisdiction the equal protection of the laws. ${ }^{165}$

162 See, Murray's Lessee v. Hoboken Land \& Inprovement Co., 59 U.S. 272 (1856); Goldberg v. Kelly, 397 U.S. 254 (1970); see also, Administrative Procedure Act §2, 5 U.S.C $\S \S 551-559(1946)$

163 U.S. Const. amend. VI, $\$ 3$.

164 Before the Constitution of 1787, local laws had already provided a similar rule: Acts of Connecticut (Revision of 1784, p. 198), of Pennsylvania, 1782 (2 Laws of Penn. 13); of South Carolina, 1788 (5 Stats. of S.C. 55); New York, 1788 (1 Jones \& Varick's Laws, 34); see also 1 Henning's Stats. of Virginia, 319, 343; 12 id. 562; Laws of Vermont (1797, 1800), 340 (emphasis added).

165 U.S. Const. amend. XIV, §2. (emphasis added) 
B. Origin of Due Process of LaW: Magna Carta of 1215, Liberty of Subject Act (28 Edward 3) of 1354, Observance of Due Process OF LAW ACT (42 EDWARD 3) OF 1368

These laws are rooted in Article 39 of the Magna Carta of 1215, whose main legacy has been the rule that a judgement must precede enforcement of penalties:

No free man shall be seized or imprisoned, or stripped of his rights or possessions, or outlawed or exiled, or deprived of his standing in any way, nor will we proceed with force against him, or send others to do so, except by the lawful judgment of his equals or by the law of the land (emphasis added) ${ }^{166} \cdot{ }^{167}$

The expression due process of law is found for the first time in the Liberty of Subject Act (28 Edward 3), de 1354, which reads as follows, verbatim: "No man of what estate or condition that he be, shall be put out of land or tenement, nor taken, nor imprisoned, nor disinherited, nor put to death, without being brought in answer by due process of the law". ${ }^{168}$ A few years later, in 1368, the term reappears in Observance of Due Process of Law Act (42 Edward 3):

At the request of the Commons by their petitions put forth in this Parliament, to eschew the mischiefs and damages done to divers of his Commons by false accusers, which often times have made their accusations more for revenge and singular benefit than for the profit of the King, or of his people, which accused persons, some have been taken and caused to come before the King's council by writ, and otherwise upon grievous pain against the law, it is assented and accorded, for the good governance of the Commons, that no man be put to answer without presentment before justices or matter of record or by due process and writ original, according to the old law of the land; and if any thing from henceforth be done to the contrary, it shall be void in the law, and holden for error. ${ }^{169}$

${ }^{166}$ Translation available from the The British Library Board. Available at: <http://bit. ly/1zrb39q > . Original text in Latin: "Nullus liber homo capiatur vel imprisonetur, aut disseisiatur, aut utlagetur, aut exuletur, aut aliquo modo destruatur, nec super eum ibimus, nec super eum mittemus, nisi per legale judicium parium suorum vel per legem terrae".

167 John Lackland, Magna Carta: A Commentary on the Great Charter of King John With an Historical Introduction 377 (William Sharp McKechnie, 2d ed. 1914).

${ }^{168}$ Liberty of Subject Act (28 Edward 3). On this subject, see Frederic Jesup Stimson, The Law of the Federal and State Constitutions of the United States: With an Historical Study of Their Principles, a Chronological Table of English Social Legislation, and a Comparative Digest of the Constitutions of the Forty-Six States 32 (1908).

169 Observance of Due Process of Law (1368). 
C. Right to a Fair Trial on the International SCEne: Declaration of the Rights of Man and of the Citizen of I789 (DéClaration des Droits de l'Homme et du Citoyen), Universal Declaration of Human Rights of 1948, European Human Rights Convention of 1950, International Covenant on Political and Civil Rights of 1966, African Charter on Human and Peoples’ Rights of 1981, Charter of Fundamental Rights of the European Union of 2000, American Convention on Human Rights of 1969

In fact, due process of law, from the procedural point of view, in the genuine sense of common law, has never had any exact equivalent in Continental European law or other international and regional legal systems. It is even confused with effective judicial protection or the right to a fair trial. ${ }^{170}$

The [French] Declaration of the Rights of Man and of the Citizen of 1789 had a tremendous impact on Continental European public law; although its origins may be associated with the declarations of the North American colonies, ${ }^{171}$ the fact is that it did not enshrine due process of law prior to administrative decisions; rather, it merely declares in Article 7 that the Judge's actions are bound by the existing statutes ("No man may be accused, arrested or detained except in the cases determined by the Law, and following the procedure that it has prescribed"), ${ }^{172}$ in contrast to Article 12 of the Massachusetts Constitution of 1780, which extends the prohibition to cases of deprivation of property without a previous fail trial. ${ }^{173}$

${ }^{170}$ See Osvaldo Alfredo Gozaíni, El Debido Proceso Constitucional: Reglas Para el Control de los Poderes Desde la Magistratura Constitucional [Constitutional Due Process: Rules for the Control of Powers From Constitutional Court Judges] 7 RevisTa Mexicana de Derecho Constitucional (2002). See also Gonzalo Garcia Pino \& Pablo Contreras Vasquez, El Derecho a la Tutela Judicial y al Debido Proceso en la Jurisprudencia del Tribunal Constitucional Chileno [The Right to Judicial Protection and Due Process in the Case Law of the Chilean Constitutional Court] 11(2) Estudios constitucionales [Constitutional studies] 229-82 (2013). See also, Luiz Guilherme Marinoni \& Daniel Mitidiero, Direitos Fundamentais Processuais [Fundamental Procedural Rights] in Curso de Direito Constitucional [Course in Constitutional Law] 615 (Ingo Wolfgang Sarlet et al., 2012).

171 Georg Jellinek, The Declaration of the Rights of Man and of Citizens: A Contribution to Modern Constitutional History 2-7, 13-21 (1901).

172 'Nul ne peut être homme accusé, arrêté, ni détenu que dans les cas determinés par la loi et selon les formes qu'elle a prescrites. Ceux sollicitent qui, expediente, exécutent ou font exécuter des ordres arbitraires, doivent être punis; Mais tout citoyen appelé ou saisi en vertu de la loi doit obéir à l'instant; il se rend coupable par sa résistance."

173 "No subject shall be held to answer for any crimes or no offence until the same is fully and plainly, substantially and formally, described to him; or be compelled to accuse, or furnish evidence against himself; and every subject shall have a right to produce all proofs that may be favorable to him; to meet the witnesses against him face to face, and to be fully heard in his defence by himself, or his counsel at his election. And no subject shall be arrested, imprisoned, despoiled, or deprived of his property, immunities, or 
Similarly to the French Declaration of 1789 , in the [United Nations] Universal Declaration of Human Rights (1948), the previous fair trial as a prerequisite for enforcement of state actions restricting individual rights is limited to criminal charges. On other matters, the Declaration of 1948 refers to a fair defence for the determination of rights and obligations of individuals, which amounts to declaring the right to judicial protection for conflict-resolution. ${ }^{174}$

And that is the predominant perspective in subsequent international conventions on what, in common law, was originally considered procedural due process of law. If, according to the letter of the U.S. Constitution, it was considered necessary for the jurisdiction (fair trial) to precede state decisions restricting any kind of individual rights (criminal charges, restriction on property rights, etc.), under the international norms, with a discreet but meaningful change in wording, only criminal charges require a previous fair trial. ${ }^{175}$

The fact that the international norms generally refer to "determination" (recognition) of rights, for the purposes of being submitted to an autonomous and impartial tribunal, does not necessarily require a trial that must be prior to the administrative decisions restricting individual rights.

The European Convention on Human Rights (1950) contains the following passage:

In the determination of his civil rights and obligations or of any criminal charge against him, everyone is entitled to a fair and public hearing within a reasonable time by an autonomous and impartial tribunal established by law." 176

The International Covenant on Civil and Political Rights (1966) provides as follows:

privileges, put out of the protection of the law, exiled or deprived of his life, liberty, or estate, but by the judgment of his peers, or the law of the land."

${ }^{174}$ Universal Declaration of Human Rights, Art. 10 (1948). (Everyone is entitled in full equality to a fair and public hearing by an autonomous and impartial tribunal, in the determination of his rights and obligations and of any criminal charge against him).

175 The principle audi et alteram partem is considered to be a common law principle of fundamental natural justice in criminal law which was subsequently extended to disciplinary administrative sanctions in Continental Europe, which became known with the Téry Decisions (Conseil d'État, 20.6.1913, S. Téry. Available at: <http://bit. ly/1Kw6kWd $>$ ), and with the Higher Administrative Court of Saxony (SächsOVG, Decision of 24 Oct. 1908, Jahrbuch, vol. 13 p. 97). See Aldo Sandulli, et al. Il Procedimento in Corso di Diritto Amministrativo. [Administrative Law Course] vol 4. Diritto Amministrativo Comparator [Comparative Adminstrative Law] 111, 113, 132 (Sabino Cassese ed., 2007).

176 European Convention on Human rights of 1950. Art. 6.1. (1950). 
In the determination of any criminal charge against him, or of his rights and obligations in a suit at law, everyone shall be entitled to a fair and public hearing by a competent, autonomous and impartial tribunal established by law. ${ }^{177}$

The African Charter of Human and Peoples' Rights (1981) maintains that "Every individual shall have the right to have his cause heard".

The Charter of Fundamental Rights of the European Union (2000) provides that "everyone whose rights and freedoms guaranteed by the law of the Union are violated has the right to an effective remedy before a tribunal", and that:

everyone is entitled to a fair and public hearing within a reasonable time by a fair and autonomous and impartial tribunal previously established by law. Everyone shall have the possibility of being advised, defended and represented. ${ }^{178}$

Finally, in the American Convention on Human Rights (1969), Article 8 on the Right to a Fair Trial provides as follows:

Every person has the right to a hearing, with due guarantees and within a reasonable time, by a competent, autonomous, and impartial tribunal, previously established by law, in the substantiation of any accusation of a criminal nature made against him or for the determination of his rights and obligations of a civil, labor, fiscal, or any other nature ${ }^{179}$.

In fact, Article 8.1 of the American Convention follows the international trend and departs from the concept originating in common law to the effect due process of law is a set of prior procedural guarantees that must necessarily be prior to any public action restricting individual rights and thus limiting itself to criminal charges.

\section{Administrative Due Process of LaW in Latin-American CONSTITUTIONS AND LAWS}

In recent years, various Latin-American constitutional norms have started to make general references to due process of law, which usually conceive of it as inherent not just in judicial actions but also in administrative actions, apparently in keeping with the spirit of the US Constitutional Amendments of 1791 and 1868 .

\footnotetext{
177 Art. 14.

178 EU Charter of Fundamental Rts., art. 47.

179 Am. Convention on Hum. RTs., art. 8.1.
} 
Article 29 of the Colombian Constitution 1991 establishes that "due process is applicable to every class of judicial and administrative action"; According to Article 5 of the Brazilian Constitution of 1988, "no one shall be deprived of freedom or of his assets without due process of law" (subsection LIV), and "litigants in judicial or administrative proceedings and the accused in general shall be assured adversary proceedings and a full defence, with the associated means and resources" (subsection LV).

According to Article 49 of the Venezuelan Constitution of 1999, “due process is applicable to all judicial and administrative acts [...]"; in the Dominican Republic, Article 69 of the Constitution of 2010 refers to "effective judicial protection and due process [...]" and subsection 10 stipulates that "the rules of due process shall apply to every type of judicial and administrative acts".

Article 34 of the Nicaraguan Constitution of 1995 specifies that:

everyone is a proceeding has the right, under equal conditions, to due process and effective judicial protection and, as part of these, the following minimum guarantees ... The minimum guarantees established in due process and effective judicial protection in this trial are applicable to the administrative and judicial proceedings. (emphasis added)

In Ecuador, Article 23.27 of the Constitution of 1998 provides that "the minimum guarantees established in due process and in effective judicial protection in this article applicable to administrative and judicial proceedings"; in the Constitution of 2008, Article 169 reads as follows:

The procedural system is a means of achieving justice. The procedural rules shall establish the principles of simplified, uniform, effective, immediate, speedy and economic trials, and shall apply the guarantees of due process. Justice shall not be sacrificed for the mere omission of formalities.

Article 76 of the Constitution of 2008, in turn, establishes that:

In every proceeding that determines any type of rights and obligations, the right of due process shall be ensured, which shall include the following basic guarantees: 1 . It is the responsibility of every administrative or judicial authority to ensure compliance with the applicable laws and the rights of the parties. (emphasis added)

In the following section, we shall discuss countries that generally provide for due process of law. Mexico, in Article 18 of the Constitution of 1917, requires that "the guarantee of due process be observed in all procedures applied to adolescents"; in Bolivia, with the Constitution of 2008, Article 115 II, stipulates that "the State guarantees the right to due process, and a universal, speedy, timely, free, and transparent system of justice and defence, without delays"; or Chile, with Article 19 of the Constitution of 1980, provides that: 
every judgement by a body that exercises jurisdiction must be based on a duly processed prior proceeding. Legislators are therefore always responsible for establishing guarantees of a rational and fair procedures and investigation.

Article 139 of the Peruvian Constitution of 1993 refers to "observance of due process and jurisdictional protection [...]"; and, finally, in Guatemala, Article 53 of the Constitution of 1965 includes a general provision according no one may be deprived of property without due process of law; and, Article 12 of the current Constitution of 1985 refers to due process of law as follows:

right to defence: the defence of the individual and of his rights is inviolable. No one maybe convicted or deprived of his rights without having been summoned, heard or convicted in a legal proceeding before a predetermined competent tribunal or judge. (emphasis added)

Regarding legislation, Argentina is worth mentioning, with its Law 19.549/72 (Ley de procedimientos administrativos), which provides, in Article 1 (f) that individuals involved in administrative procedures have the right to procedural due process; in Uruguay, with its Article 5 of the Ley de procedimientos administrativos, according to which individuals involved in administrative procedures enjoy the rights and guarantees inherent in due process.

\section{E. Case Law of the European and Inter-American Courts of Human Rights: INDEPENDENCE AND IMPARTIALITY IN NON-JUDICIAL Administrative Proceedings, and Due Process of Law Prior to AdMinistrative DeCisIONS}

In fact, there are many points in common between procedural due process of law, in the form in which it evolved in the United States, and the right to a fair trial of the European Convention of Human Rights, especially the fact that both of them are applicable to administrative cases, as originally provided for by U.S. constitutional law.

In that respect, despite the controversy surrounding the expression civil rights and obligations in Article 6.1 of the Human Rights Convention in relation to administrative law conflicts, the European has interpreted this clause to be binding not only on the courts:

the Court is not prevented from qualifying a particular domestic body, outside the domestic judiciary, as a "court" for the purpose of the Vilho Eskelinen test. An administrative or parliamentary body may be viewed as a "court" in the substantive sense of the term, thereby rendering Article 6 applicable to civil servants' disputes. The conclusion as to the 
applicability of Article 6 is, however, without prejudice to the question of how procedural guarantees were complied with in such proceedings. ${ }^{180}$

The Inter-American Court of Human Rights follows the same orientation as the European Court: it interprets the expression "Garantias Judiciales" or Judicial guarantees (translated as "Right to a Fair Trial" in the official English version) contained in the title of Article 8 of the Inter-American Convention does not prevent other state bodies unrelated to the Judiciary from trying the merits of the case and from [being required to] observe the guarantees of due process of law. ${ }^{181}$

When examining a decision of the Uruguayan Administrative Court, the Inter-American Court point out that:

it was very specific and precise in establishing that certain components of the guarantees necessary for ensuring due process are also applicable to in the non-judicial sphere in a context in which issues related to personal rights may be under discussion. Thus, the Court has understood in its previous case law that the characteristics of impartiality and independence [...] should be mandatory for any body in charge of ruling on the rights and obligations of individuals. With that in mind, [...] they should not only correspond to strictly jurisdictional bodies but the provisions of Article 8.1 of the Convention are also applicable to administrative decisions. ${ }^{182}$ )

There is one characteristic of due process of law, however, conceived in 1792, that is irreconcilable with the right to a fair trial [processo efetivo], as interpreted by the European Court, that is of great importance for understanding the current stage of administrative justice in the Latin America: the prior nature of procedural due process of law. It does not form part of the legal tradition of Continental Europe or of Latin-American administrative law: the existence of a proceeding (trial) that is conducted under the responsibility of an autonomous or quasi-judicial administrative authority and generally precedes the enforcement of the relevant administrative decision. ${ }^{183}$

180 Volkov v. Ukraine, 2010 Eur. Ct. H.R. 1. Along the same lines (as a paradigm). Eskelinen v. Finland. 2007 Eur. Ct. H.R. 1, See Rene Chapus, Droit Du Contentieux Administrative [Law Of Administrative Disputes] 136-38 (12 ${ }^{\text {th }}$ ed. 2006). See also Sergio Bartole Et Al., Commentario Breve Alla Convenzione Europea per la Salvaguardia dei Diritti Dell'Umo e Delle Libertà Fondamentali. [Short Commentary on the European Convention for the Protection of Human Rights and Fundamental FREEDOMS] 176 (2012); BARRETO, supra note 30.

${ }_{181}$ Constitutional Court v. Peru, Judgment of 31 Jan. 2001. 01. Series C No. 142.

${ }^{182}$ Vélez Loor v. Panama, Preliminary Defences, Merits, Damages and Costs, Judgment, Inter-Am. Ct. H.R. (ser. C) No. 218, 108 (Nov. 23, 2010) (emphasis added).

183 See Asimow, supra note 9. 
A debate is therefore necessary, at the current state of ContinentalEuropean law, in order to discuss whether due process of law should be considered an integral part of administrative actions restricting individual rights (initial administrative decisions) or should only be considered to form part of the decisions (judicial or non-judicial decisions) that settle conflicts concerning administrative actions that have already restricted an individual's rights or are in the process of doing.

According to the European Court case law, if the national laws provide means of appealing an administrative decision, they should be subject to the rules of Article 6.1 of the Convention; thus, if such means are absent, the Convention is applied only in the appellate phase, which demonstrates that a prior proceeding is not a sine qua non for administrative decisions to arise; moreover, if the appeal is made before the Judiciary, the independence of the decision-making administrative authority even becomes dispensable.

In this context, the right to a fair trial implies a means of appeal rather than a constituent element of the administrative decision. The practical difference is substantial: while under the system of a right to a fair trial, the challenged administrative decision only ceased to be effective ab initio in the case of periculum in mora and fumus boni iuris (for which the claimant bears the burden of proof), in an interim relief measure, under the system of due process of law, the administrative decision does not enter into effect until after the completion of the preliminary proceeding, and inversely, the exception to that rule depends on periculum in mora and fumus boni iuris, both of which must be proven by the the administrative authority ${ }^{184}$.

\section{F. Distinction Between the Judicial Administrative Proceeding (Processo Administrativo Judicial), Non-Judicial Administrative ProceEding (Processo Administrativo Não JUdicial) and Administrative Procedure (Procedimento Administrativo)}

The Latin-American doctrine according to which prior administrative due process (debido procedimiento administrativo) is a sine qua non for the elaboration of administrative decisions restricting individual rights is merely rhetorical. ${ }^{185}$ That is so because such measures are most never correspond

184 See North American Cold Storage Co. v. Chicago, 211 U.S. 306 (1908).

185 Regarding the consensus in the Latino-American doctrine on the application of due process. See Augustin Gordillo, Tratado de Derecho Administrative [Treatise on Administrative Law] vol. 2, 284 (2004); Allan R. Brewer-Carias, Principios del Procedimiento Administrativo en América Latina [Principles of Administrative LaW in Latin America] 262 (2003); Ernesto Jinesta, Debido Proceso en la Sede Administrativa: Derecho Administrativo en el Siglo XXI, [Due Process in the AdministraTIVE SpHERE] vol. 1, 581-611 (2013); Alan E., Vargas Lima, Desarrollo Jurisprudencial de la Ley de Procedimiento Administrativo en Bolivia [Jurisprudential Development of the Law of Administrative Procedure in Boliva] LA RAzón, (May 13, 2014, 12:00 A.M.), http://bit.ly/150BMf7. The Model Code of Administrative Proceedings - Judi- 
to reality, from the use of the expression administrative procedimiento (procedure) on to the claim of impartiality without independence from the authorities ${ }^{186}$.

Even in the late $19^{\text {th }}$ Century, the administrative jurisdiction was still confused with the administrative authorities' power of autotutela [power to correct its own illegal mistakes], that is to say that administrative disputes were tried by the administrative authorities themselves. ${ }^{187}$ Thus, the expression administrative proceeding (processo) could not be used outside the scope of the Executive; and in some cases not even in the Executive, when it was not capable of establishing autonomous bodies to resolve disputes.

The proceeding is inherent in the jurisdiction, and neither of them can dispense with autonomous management in relation to the parties to the dispute. ${ }^{188}$ The judges' concern for maintaining independence from the monarchy dates back to Article 39 of the Magna Carta de 1215; it is inconceivable for a judge to try his own case.

Independence was not only the spark that gave rise to administrative justice in the $19^{\text {th }}$ Century and to the development of specific administrative law, but even today it is considered to be an element inseparable from the jurisdictional function. Independence is expressly incorporated into a number of different national and international norms, such as the European Convention of Human Rights (Article 6.1) and the American Convention on Human Rights (Article 8.1).

It is therefore possible to argue that in the period in which it was inconceivable for administrative jurisdiction to be autonomous from the public administrative authorities, the expression processo administrativo (administrative proceeding) was inapplicable. The expression of will of the administrative authorities involving the citizen could be called a procedimento administrativo (administrative procedure), although that term would be more appropriate for administrative actions that were interna corporis or that could not place the rights or interests of individuals at risk.

cial and Non-judicial - for Ibero-America lays down principles governing due process of law for judicial proceedings [art. 37] and implicitly for non-judicial proceedings [arts. 6 and 7]; an administrative proceeding is considered to be any proceeding, subject to guarantees of an adversarial hearing and a full defence, that is intended to prepare administrative decisions that may affect the interests or rights of private citizens, as well as any procedure in which a public- or private-law dispute arises between an administrative authority and a citizen, or a dispute between individuals or legal entities that may be resolved by an administrative authority [art. 3]. Grinover et al., supra note 62.

186 See S. Ferraz \& A. Dallari, Processo Administrativo [Administrative Proceedings] 138 (2d ed. 2007) (Regarding the lack of independence and resulting lack of impartiality of the authorities in the punitive proceeding).

187 See parts I. B \& C.(especially note 45 supra).

188 See Oskar von Bülow, Die Lehre von den Processeinreden und den Processvoraussetzungen [The Doctrine of Procedural Defences and Prerequisites for Trial] 1-12 (Emil Roth Giesen ed., 1868). 
By gaining independence vis-à-vis the administrative authorities, the administrative jurisdiction tended to move away from the Executive, and so did the corresponding (administrative) proceeding. In the case of an administrative jurisdiction before the Judiciary, the processo administrativo (administrative proceeding) should be qualified by the term judicial: processo administrativo judicial (judicial administrative proceeding).

However, the jurisdiction is not always before the Judiciary, as, for example, in the system of non-judicial administrative jurisdiction (justice déléguée), which currently exists in Uruguay and Mexico. According to Monroy, "the dilemma of jurisdiction is not who exercises or personifies it but what it fundamentally means". ${ }^{189}$ In fact, in order for a jurisdiction to become autonomous, it need only detach itself from the authority involved in the conflict, and not necessarily from the Executive by means of an administrative agency and its administrative judges as in the United States, where procedural due process of law is sought within the Executive. ${ }^{190}$

At any rate, in this case, the expression processo administrativo [administrative proceeding] would be correct in relation to a non-judicial administrative jurisdiction and, to differentiate it from a processo directed by the judicial authorities (which would also be a fair trial), it is called a nonjudicial administrative proceeding (processo administrativo não judicial).

However, not infrequently in certain Latin-America legal systems the processo administrativo is associated with situations in which there is no autonomous jurisdiction or, more precisely, where there are no guarantees of due process of law (a fair trial); and vice-versa: procedimento administrativo [administrative procedure] is used to refer to situations in which there is an autonomous jurisdiction. ${ }^{191}$

In the Brazilian legislation, ${ }^{192}$ the expression processo administrativo is used to characterise procedimentos insofar as the processo in Brazil, in practice, are conducted by organisations or administrative authorities

189 Juan F. Monroy Gálvez, Teoría General del Proceso [General Theory of the Trial]; 419 (2009).

190 This model of "adversarial hearing/combined function/limited judicial review," in which the decision-making administrative authorities belong to the Executive Branch does not have any equivalent in Latin America; Honduras recognised a system of hybrid jurisdiction from 1965 to 1982 but the administrative tribunal was autonomous vis-à-vis both the Judiciary and the Executive. Asimow, supra note 9, at 3-32.

191 According to Manuel María Diez, "algunos autores usan los términos proceso y procedimiento como sinónimos. Esta posición es insostenible, ya que no se pueden identificar ambas instituciones ignorando el problema que presentan" ["certain authors use the terms "proceso" and "procedimiento" as synonyms. That position is untenable since the two insitutions cannot be confused without being aware of the resulting problems]. Pedro Aberastury \& Maria Rosa Cilurzo, Curso de Procedimiento Administrative, 17 (1998).

${ }^{192}$ Lei no. 9.784, de 29 de Janeiro de 1999 (Law on federal administrative proceedings). 
which lack prerrogatives to act with effective independence; ${ }^{193}$ the LatinAmerican Constitutions and laws that provide for due process of law do so by inserting it within a declared administrative procedimento.

In Continental Europe, the expression processo administrativo (administrative proceeding) is used to refer to the courts or to a proceeding in progress before an autonomous or non-judicial authority: a procedimento administrativo is a procedure that is carried out with a body that lacks autonomous jurisdiction.

\section{G. Administrative Due Process Prior to Decisions by Administrative Authorities in Latin America}

Administrative law in Latin America is more heavily influenced by the European tradition than by the spirit of the laws of due process. In Latin America, the system of undivided jurisdiction prevails and its courts commonly make up for the absence of prior due process of law by means of broad judicial review in which those same guarantees are provided. ${ }^{194}$ In practice, however, the logic of due process of law becomes ineffectual in the administrative sphere.

In addition, the reality of the Latin-American administrative authorities is not compatible with a system of autonomous or quasi-autonomous authorities. The few examples are in the area of access to official information, supported by the Model Inter-American Law on Access to Public Information, ${ }^{195}$ as in Mexico, with the Federal Institution of Information Access and Data Protection ${ }^{196}$ in Chile, with the Transparency

193 Regarding certain obstacles in Brazil to creating truly autonomous agencies. See Vera Scarpinella Bueno, Devido Processo Legal e a Administração Pública no Direito Administrativo Norte-Americano: Uma Breve Comparação com o Caso Brasileiro [Due Process of Law and Public Administrative Authorities in U.S. Administrative Law: A Concise Comparison with the Case of Brazil] in Devido Processo Legal na AdministraÇão Pública [Due Process of Law in Public Administrative Authorities] 75 (Lucia Valle Figueirido ed., 2001).

194 See TRF2, AC 2003.51.03.002508-3, Fed. App. Reporting Judge Aluisio Mendes: [...] despite the fact that the judgement and now the decision appealed against acknowledged an irregularity in the administrative act which split [the deceased's] pension to the benefit of the life companion, namely the failure to notify the widow, that irregularity was found to be completely irrelevant when submitted to the scrutiny of the Judiciary, so that there is no obstacle to upholding the above-mentioned act." (Available at: $<$ http://bit.ly/1q7mSOy>).

195 Organization Of American States (OAS). Plenary Session 4, AG/RES. 2607 (XL0/10) Model Inter-American law on access to Public Information. Washington, June 8, 2010.

196 Art. 33 of the Ley Federal de Transparencia y Acceso a la Información Pública Gubernamental [Federal Law on Transparency and Access to Public Governmental Information] of 2002. Currently, the Instituto and the Organismos Garantes, contained in arts. 
Council; ${ }^{197}$ in Honduras, with the Institution of Commissioners [Instituto de Comissários]; ${ }^{198}$ and in El Salvador, with the Public Information Access Institution [Instituto de Acesso à Informação Pública]. ${ }^{199}$

The classic border between administrative functions and jurisdictional functions, according to Monroy,

is provided by the primary and secondary effect that they produce, respectively, in the area of social relations. The administrative activity is primary insofar as it is designed to be performed immediately and directly vis-à-vis citizens; on the other hand, jurisdictional activity is secondary: i.e., it is only present when laws that are intended to be complied with spontaneously, including administrative laws and the actions of the authorities are rejected by citizens and a mechanism is necessary to ensure their effectiveness or compliance in a voluntary or forced manner. ${ }^{200}$

This explains the reluctance to admit the primary jurisdiction, i.e., a jurisdiction prior to the administrative decision and, especially, as an integral part of it.

This situation is not changed by the case law of the Inter-American Court of Human Rights which, following the example of the European Court, requires a fair trial (effective proceeding) by an autonomous tribunal for administrative cases within the public administrative authorities. ${ }^{201}$ This is so because the jurisdiction to which it refers in its precedents, despite its non-judicial nature, does not necessarily include the contents of the initial administrative decision and is mainly used for any conflicts resulting from such decisions; in other words, the case law of the European and Inter-American Courts relates to non-judicial bodies, such as the French Council of State or Uruguayan Administrative Court - which is not equivalent to a public administrative authority with primary - merely executive or jurisdictional -- functions. ${ }^{202}$

8, III e IV, 30, 37-42 of the Mexican Law of May, 42015 (Ley General de Transparencia y Acceso a la Información Pública).

197 Art. 31 of the Law No. 20.285/2008 (Ley sobre el Acceso a la Información Pública [Law on access to public information]).

198 Art. 8 of the Legislative Decree No. 170/2006 (Decreto No. 170/2006, Ley de Transparencia y Acceso a la Información Publica [Law on Transparency and Access to Public Information]).

199 Arts. 51 to 60 Decree no 534/2011 (Ley de Acceso a la Información Publica [Law on Access to Public Information]),

200 GálveZ, supra note 189 , at 418.

201 See the precedents in note 180 supra.

202 The European Court held that Councils of State situated outside the Judiciary and exercising functions of administrative jurisdiction are compatible with the Convention provided that the advisory functions are not concentrated in the judges to the dispute (Judgement in Procola v. Luxembourg delivered by the Court on 28 September 1995; 
In reality, regarding the procedure prior to restrictive administrative decisions, the Inter-American Court decided that:

the guarantees contemplated in Article 8.1 of the Convention are also applicable to cases in which a certain public authority adopts decisions that rule on such rights ${ }^{203}$, taking into account that although it cannot be required to provide the guarantees characteristic of a jurisdictional body it must nonetheless provide the guarantees designed to ensure that the decision will not be arbitrary ${ }^{204}$.)

The scholarly writings of Hispanic Latin America have preferred the expression debido procedimiento legal to differentiate it from due process of law, which is inherent only in a judicial proceeding (trial) conducted before an autonomous body. However, besides the risk of confusion with procedural due process of law (the counterpart of substantive due process of law), it fails to answer the essence of the question: Is an (autonomous) jurisdiction inherent in an initial administrative decision or not?

There can be no doubt that autonomous jurisdiction is not an exclusive function of the Judiciary; it can be exercised by the Executive. It would be mere speculation to project the present debate into a past period when the Judiciary supposed to devote itself exclusively to questions of private law and the Executive to public law (ruling on disputes, as well) - at the time, an autonomous administrative decision-making body was inconceivable.

It is therefore time to confront the central topic of this article: the prior nature that is required for observance of due process of law in the acts of the public administrative authorities, as expressed in U.S. administrative and constitutional law, ${ }^{205}$ and in the Latin-American laws and constitutions, even though no corresponding concept is to be found in the InterAmerican Convention of Human Rights and in the European Convention of Human Rights.

Is due process of law, through jurisdiction, a prerequisite for the formation of an administrative decision restricting individual rights under Latin-American law?

Judgement in Kleyn et al v. the Netherlands, delivered by the Court on 6 May 2003, available at http://bit.ly/1DVyklu). See Bartole, supra note 180, at 176.

${ }^{203}$ See Case of the Constitutional Court v. Peru, Judgement of 31 January 2001. 01. Series C No. 71, para. 71, available at http://bit.ly/1UwcKLE; Case of Yatama v. Nicaragua, \149, available at http://bit.ly/1iW2yHU; and the Case of Claude Reyes and others v. Chile, $\$ 119$, available at $\mathrm{http} / / / \mathrm{bit} . \mathrm{ly} / \mathrm{LLSjyMB}$.

${ }^{204}$ See the Case of Claude Reyes and others v. Chile, $₫ 119$, (emphasis added).

205 See Richard J. Pierce, et Al., Administrative Law And Process 231 (4th ed. 2004). Regarding the essentially jurisdictional nature of the preparatory administrative proceedings for administrative decisions in the United States, see Odete Medauar, A Processualidade no Direito Administrativo [The Nature of Proceedings in Administrative LAW] 83 ( $2^{\mathrm{d}}$ ed., 2008). 
In reality, according to the letter of most of the laws in force in Latin America, what is required is for the administrative decision to originate from a fair proceeding, in order words, observance of the prior guarantees of due process of law is a condition precedent for the enforcement of administrative decisions. That is the mens legis.

In this context, if the State requires but does not provide for prior jurisdiction by means of a non-judicial administrative proceeding offering the guarantees of a fair trial, the logical corollary will be for judicial proceeding to perform that function and to serve as a protective instrument prior to the enforcement of an administrative decision restricting an individual's rights; this, in turn, would to undesirable results, as shown in the introduction to this paper: exacerbated judicial review, made even worse by a monist judicial system with non-specialised judges (although there are occasionally specialised bodies in the monist system, the judges have not been organised in a specialised career path).

It is insufficient to argue that compliance with the due process of law clause could be ensured even without a prior non-judicial administrative proceeding if a rejected claimant party could have recourse to a judicial means of challenging the decision, unless that judicial means of challenge automatically (unconditionally) suspended the enforceability of the disputed administrative decision and also involved a trial with full powers of review; that is the only way that would make it equivalent to a judicial (or essentially jurisdictional) proceeding prior to an administrative decision restricting the rights of an individual. ${ }^{206}$

From a different perspective, regarding administrative decisions made at the request of an individual, the question has now been examined whether the petitioner should have the option of [first] exhausting the recourses in the non-judicial administrative channels or else initiate judicial proceedings immediately. ${ }^{207}$ In effect, that option does not correspond to suitable organisation of the state: if the non-judicial administrative appeal is nontransferrable, it should be rejected. There are only two possibilities: either the non-judicial administrative appeal is indispensable as a prerequisite for access to a judicial proceeding or it has no function at all and should be discarded (as a prerequisite for access to a judicial action).

On the other hand, from a more rigid perspective, to affirm that the prior administrative appeal as a prerequisite for legal action is necessary on the grounds that the authorities that the authorities have the exclusive right to reverse their decisions ${ }^{208}$ amounts to confusing the $19^{\text {th }}$-Century concept

${ }^{206}$ Regarding the automatic suspensory effect on the implementation of an administrative decision created by filing a judicial appeal, see Ricardo Perlingeiro \& Karl Peter Sommermann, Euro-American Model Code of Administrative Jurisdiction: English, French, German, Italian, Portuguese and Spanish Versions (2014).

207 See $i d$. Article 32.

208 See Ricardo Perlingeiro et al., Principes Fondamentaux et Règles Génerales de la Juridiction Administrative [Fundamental Principles and General Rules of Administrative Jurisdiction], 163 Revista de Processo, at 262 (2008). 
of the power of autotutela [the authority's power to correct its own illegal actions] with the contemporary concept of administrative dispute resolution. The indispensability of the prior proceeding (non-judicial administrative appeal) should be proportional to its effectiveness and, consequently, to the limits of review in any posterior judicial review. ${ }^{209}$

Thus, there are two possibilities: either the proceeding is started at the initiative of petitioner appealing against a decision denying his petition that was issued at the end of a fair proceeding conducted by autonomous authorities, or else such a proceeding becomes merely decorative and should be discarded. However, as in the previous situation (proceeding initiated ex officio), if a non-judicial administrative appeal results in another decision against the petitioner in the appellate phase, then we should rethink the scope- intensity - of appropriate judicial supervision to avoid the risk of creating overlapping jurisdictions.

It would lead to an undesirable duplication of jurisdictions to a adopt a fair and impartial hearing (procedural due process) prior to the [enforcement of the] administrative decision, while at the same time maintaining a judicial system of administrative jurisdiction (monist or dualist) or a nonjudicial jurisdiction with broad powers of review (exhaustive review), in both cases, a posteriori to the administrative decision. ${ }^{210}$ The alternative seems to tend toward the U.S. model of judicial review: a hybrid system of administrative jurisdiction.

\section{Closing Considerations}

The historical evolution of the administrative jurisdiction in Europe from the $19^{\text {th }}$ Century shows that independence is a vital prerequisite for its existence; the location of that jurisdiction within the structure of the state is of merely secondary importance: whether on the level of the Judiciary, the Executive, or divided between the two, or in entities that are autonomous from both the Judiciary and the Executive.

Administrative jurisdiction is currently conceived of as inherent in a fair trial and must not be confused with the primary actions of public

${ }^{209}$ On the scope of judicial administrative jurisdiction as proportional to the effectiveness of the prior administrative decisions, see, in general, PerLingeIro, supra note 3, at 293331 (2015); Asimow, supra note 9, at 3-32.

210 Asimow, supra note 9. Mairal, supra note 155, at 714; Julio V. GonzÁlez García, El Alcance del Control Judicial de las Administraciones Públicas en los Estados Unidos de América [The Scope of Judicial Revew of Public Administrative Agenices in the United States of America] 37 (1996). 
administrative authorities, understood to be purely executive, sometimes resulting from procedimentos administrativos [administrative procedures].

Based on such premises, the combination of the organisation of the administrative jurisdiction within the state (non-judicial, judicial or hybrid; monist or dualist) and the nature of the means of elaboration of administrative decisions that restrict the rights and interests of individuals (whether based on proceedings or procedures) lays the groundwork for the formation of a model of administrative justice.

The scope and intensity of the administrative jurisdiction are proportional to the level of specialisation of the state bodies by which it is exercised; the greater the scope and intensity of the jurisdiction prior to the formation of the administrative decision (prior review), the less important the bodies devoted to a posteriori jurisdiction (subsequent review) will be; and vice-versa: both the duplication and the absence of jurisdiction are undesirable.

It is therefore necessary to analyse the optimal point in time for the administrative jurisdiction: review before or review after the formation of the administrative decision?

In the current legal system of Latin-American countries, the fair trial is advocated as inherent in the formation of administrative decisions, and due process of law is expressly adopted; besides that, since the $19^{\text {th }}$ Century, the judicial system of monist jurisdiction has predominated in Latin-American.

On the model of the common law countries, it would be natural to imagine in Latin America a reinforced non-judicial administrative jurisdiction prior to administrative decisions (primary jurisdiction) side by side with a non-specialised judicial jurisdiction that is prone to show deference to administrative decisions.

In practice, however, the opposite situation occurs: there are no administrative proceedings and no jurisdiction that is really prior to the administrative decision; and the Judiciary, which lacks an autonomous administrative jurisdictional structure, occasionally endeavours to form special administrative sections.

The US influence on the Latin-American model of administrative justice seems to be outweighed by the Continental-European Tradition.

In this context, where the current legislation is divorced from reality, we are trying to determine where the Latin-American administrative jurisdiction is heading. How can we interpret the evolutionary historical framework of its administrative justice over the 200 years of its existence and put it in perspective?

Even after the influence of the U.S. Constitution with respect to the unified judicial system, in the early $19^{\text {th }}$ Century, and of administrative and procedural due process of law in the late $20^{\text {th }}$ Century, Ibero-America, naturally oriented by civil law, remains tied to the culture of ContinentalEuropean administrative law.

The transformations undergone by administrative law in European countries have not been followed in Latin America, however, resulting in a lacuna in its administrative justice system that can still be felt today. 
In the Europe of the first half of the $19^{\text {th }}$ Century, discussions were raised about an administrative jurisdiction separated from the public administrative authorities, even in the hands of a specialised Judiciary; in contrast, in Latin America, the constitutions of the period did not even tackle the subject but contented themselves with creating a Judicial Branch to try "administrative disputes" (contentieux administratif) commensurate with the cases that were tried in $18^{\text {th }}$-Century Europe, that is to say, in practice, restricted to what would now be considered private-law conflicts involving the administrative authorities, since, in that century, the range of governmental actions (acte du gouvernement) immune to jurisdiction was defined too broadly.

The evolution of administrative jurisdiction in Europe gradually became noticed in Latin America in various ways; it was not until the end of the $19^{\text {th }}$ Century that timid experiments were begun with a system of specialised jurisdiction which, in certain countries, was tied to the Judiciary and, in others, separated from both the Judiciary and the Executive. This system is currently found in only five different Latin American countries: Guatemala, the Dominican Republic, Colombia, Uruguay and Mexico.

The absolute majority of the Latin-American countries have adopted the unified judicial system, which, however, since it is inherent in common law, was not easily assimilated by them and made little progress towards the innovations displayed by US administrative law from the late $19^{\text {th }}$ Century: with administrative authorities capable of conducting a fair trial as a prerequisite for the elaboration of administrative decisions, which tended to be challenged by the Judiciary only when they were [obviously] illegal and unreasonable.

In that respect, the Judiciary's lack of specialisation and constant deference to the administrative authorities in the United States were made up for by the increasing effectiveness of due process of law in non-judicial sphere prior to the formation of administrative decisions (primary jurisdiction).

It wasn't until the late $20^{\text {th }}$ Century, when democracy was restored to much of Latin America, that the Judiciary started exercising more intense supervision of administrative actions (including the use of discretionary powers) and began to create certain adjudicating bodies specialising the field of administrative law.

The excessive load on the courts, however, is the most obvious sign that the system has failed.

The occasional specialised bodies - typical of the monist judicial system - are incapable of avoiding the trend of their judges to show favouritism towards administrative actions or (in the exceptional cases in which they act more boldly) of eliminating the mistrust of the jurisdiction aroused by the administrative authorities, who claim that the courts are abusing their authority and that the judicial decisions are of doubtful quality.

Moreover, in Latin America, civil servants in positions of authority do not always have legal expertise and, in most cases, their duties include both investigation and decision-making in the context of administrative procedures that result in decisions restricting the rights of individuals. 
Now that it has become firmly established that administrative decisions are subject not only to the applicable statutes but also to the supremacy of constitutional law and international human rights conventions -- a concept which has become ingrained in Latin-American and Continental European legal doctrines and encouraged by the case law by the European and Inter-American Courts of Human Rights - public administrative authorities are required to have a high level of legal expertise, along with a certain degree of independence in decision-making.

It is also extremely important to understand that the effects of administrative decisions on the interests of private citizens, guided by respect for their fundamental rights, must be the result of fair hearing, in which the decision-making authorities must not be confused with the executive authorities.

In this context, it is inevitable to conceive of an administrative jurisdiction that is implemented in two distinct phases, before and after the elaboration of the administrative decision, in order to satisfy both the need for all public institutions to respect the Rule of Law and the guarantee of effective judicial protection, although not necessarily in the hands of the Judiciary.

Without many alternatives, this is currently the road that should be followed by the administrative jurisdiction in Latin America.

The panorama of Latin-American constitutional and statutory law makes it strikingly clear that administrative jurisdiction must be handled by a Judiciary that lacks a specialised structure (except for the five countries mentioned above), while at the same time due process of law must clearly be a constituent element of administrative decisions that restrict the rights of individual.

It has therefore become urgently necessary to advocate a reform of the State by endowing it with a structure capable of conducting prior jurisdictional proceedings through civil servants trained in law and autonomous, impartial and specialised administrative authorities.

As the State becomes structured in such a way as to create a primary jurisdiction for the elaboration of administrative decisions, a posteriori jurisdictional supervision will cease to be the only protective mechanism and the interests of the individual will be safeguarded better, because citizens will not have to suffer the consequences of a decision against them until they have first had an opportunity to defend themselves in a fair trial.

If the Continental-European legal system now co-exists with non-judicial procedures prior to administrative decision and a predominantly $a$ posteriori administrative jurisdiction it is because its culture enables administrative authorities, despite their lack of independence, to act with reliable degrees of impartiality.

The same cannot be said of Latin America, however, where it would be advisable to split the jurisdiction (corresponding to a proceeding conducted by autonomous judges or authorities) by shifting part of it to a non-judicial phase prior to the formation of the administrative decision.

The Latin-American of model administrative justice tends to rely on European experience but it cannot continue to draw its inspiration from 
that source because, paradoxically, it would not provide individuals with sufficient guarantees in today's Latin America.

The Latin-American model is moving towards a transitional phase, in search for the implementation of the administrative due process of law that is enshrined in its constitutions and laws and inherent in its unified judicial system that has been in force for 200 years.

Finally, the Latin-American organisational model is tending to move towards the hybrid jurisdictional system of the United States, experienced by Honduras in the 1960s and 80s, but which is not completely similar to it. It is a model that tends to preserve its own identity because the LatinAmerican experience with non-judicial jurisdiction has moved towards bodies and tribunals that are autonomous from the Executive, as we have seen in Bolivia, Panama, the Dominican Republic, Colombia, Guatemala, Ecuador and Uruguay in the $19^{\text {th }}$ and $20^{\text {th }}$ Centuries. 
